\title{
Fisheries and Tourism: Social, Economic, and Ecological Trade-offs in Coral Reef Systems
}

\author{
Liam Lachs and Javier Oñate-Casado
}

\begin{abstract}
Coastal communities are exerting increasingly more pressure on coral reef ecosystem services in the Anthropocene. Balancing trade-offs between local economic demands, preservation of traditional values, and maintenance of both biodiversity and ecosystem resilience is a challenge for reef managers and resource users. Consistently, growing reef tourism sectors offer more lucrative livelihoods than subsistence and artisanal fisheries at the cost of traditional heritage loss and ecological damage. Using a systematic review of coral reef fishery reconstructions since the 1940s, we show that declining trends in fisheries catch and fish stocks dominate coral reef fisheries globally, due in part to overfishing of schooling and spawningaggregating fish stocks vulnerable to exploitation. Using a separate systematic review of coral reef tourism studies since 2013, we identify socio-ecological impacts and economic opportunities associated to the industry. Fisheries and tourism have the potential to threaten the ecological stability of coral reefs, resulting in phase shifts toward less productive coral-depleted ecosystem states. We consider whether four common management strategies (unmanaged commons, ecosystem-based management, co-management, and adaptive co-management) fulfil eco-
\end{abstract}

L. Lachs $(\bowtie)$

Marine Biology, Ecology and Biodiversity, Vrije Universiteit Brussel, Brussel, Belgium

Institute of Oceanography and Environment, Universiti Malaysia Terengganu, Kuala Terengganu, Terengganu, Malaysia

Department of Biology, University of Florence,

Sesto Fiorentino, Italy

J. Oñate-Casado $(\triangle)$

Department of Biology, University of Florence,

Sesto Fiorentino, Italy

Sea Turtle Research Unit (SEATRU), Universiti Malaysia

Terengganu, Kuala Terengganu, Terengganu, Malaysia

School of Biological Sciences, University of Queensland, St Lucia, QLD, Australia logical conservation and socioeconomic goals, such as living wage, job security, and maintenance of cultural traditions. Strategies to enforce resource exclusion and withhold traditional resource rights risk social unrest; thus, the coexistence of fisheries and tourism industries is essential. The purpose of this chapter is to assist managers and scientists in their responsibility to devise implementable strategies that protect local community livelihoods and the coral reefs on which they rely.

\section{Keywords}

Sustainable development - Adaptive co-management .

Systematic review $\cdot$ Ecological impacts $\cdot$ Economic shift

\subsection{Context}

Coral reef ecosystems are considered one of the most productive and economically valuable ecosystems on Earth, providing habitat for a highly diverse species assemblage (Roberts et al. 2002). Various global and local stressors threaten coral reefs, from global warming-induced heat stress to tourismand fisheries-induced ecological stresses. The result of overuse and overexploitation by either of these industries can be disastrous for the reef ecosystem (Hodgson and Dixon 1988; Hawkins and Roberts 1994; Cesar et al. 2003; Fenner 2012; Jackson et al. 2014; Gil et al. 2015). While both industries present economic opportunities necessary for coastal communities in the vicinity of coral reefs (Cesar et al. 2003), they often compete for the same operational spaces (Fabinyi 2008). This review draws on the history of tourism and fisheries industries from around the world to answer questions about how best to manage these growing industries in the future. We unravel the different ecological threats posed by fisheries and tourism and discuss the trade-offs managers make to minimize coral reef degradation. Considering the benefits and pitfalls of various management strategies, we 
compare the social, ecological, and economic trade-offs that coral reef stakeholders must make to successfully tread the path of sustainable socioeconomic development. We also highlight various tools available for the benefit of local communities in coral reef systems.

Although we do not consider the effects of global change on coral reef social-ecological systems in this review, it is important to frame our discussion and management recommendations on the backdrop of a changing world. Coral bleaching occurs when excessively high water temperatures invoke decoupling of coral host tissue and symbiotic algal zooxanthellae (Bessell-Browne et al. 2014). With a reduced metabolism, bleached corals have higher probabilities of falling victim to starvation, disease, predation, or competition (Bellwood et al. 2006). Mass bleaching events occurred around the world in 1998, 2002, 2010, and 2016, whilst individual coral reefs are experiencing ever more frequent bleaching events (Heron et al. 2016). During the 2016 bleaching event in the Great Barrier Reef (GBR), less than $8.9 \%$ of reefs escaped without bleaching, compared to $42.4 \%$ in 2002 and $44.7 \%$ in 1998 (Hughes et al. 2017). Similarly, coral reefs in the Maldives bleached extensively in 2016, with live coral cover dropping below $6 \%$ in the southern Maldivian reefs (Perry and Morgan 2017). Mass coral bleaching has the potential to wipe out wide swathes of coral reefs, transitioning the ecosystem toward degraded states (Fig. 13.1) with detrimental impacts to global biodiversity and both coastal tourism and fisheries economies. Therefore, we must frame our arguments on the trade-offs between fisheries and tourism against a backdrop of unprecedented global change and the worst-case scenario.

\subsection{Ecosystem Services}

As the most biodiverse of marine habitats, coral reefs provide a wide range of ecosystem services, from fisheries and recreation/tourism to coastal protection and potential medical innovation, which in turn drive the social, ecological, and economic trade-offs discussed in this chapter. Coral reef fisheries provide a key source of income and livelihood to coastal communities, are a non-substitutable source of protein for many island populations (Laurans et al. 2013), and are key to culturally significant local traditions (McClanahan 1999; Bruggemann et al. 2012; Fenner 2012). Growing tourism industries, based on recreational activities such as snorkeling, diving, whale watching, and recreational fishing (Asafu-Adjaye and Tapsuwan 2008; Young et al. 2015; Chen et al. 2016a) require different skill sets than traditional livelihoods and offer alternative income to coastal communities (Hicks et al. 2013; Harvey and Naval 2016; Outra et al. 2016). The structure of carbonate reefs directly protects coastal areas, especially in tsunami- and storm-prone tropi- cal regions of the Indian and Pacific Oceans (Ferrario et al. 2014), and indirectly protects these areas through supply of carbonate sand to beaches and mangrove ecosystems (Wells et al. 2006). Coral reef biodiversity, from coral and algae to cone shells and sponges, provide many novel compounds useful to medical science including painkillers and antiviral, antimicrobial, and anticancer drugs (Kelman et al. 2001; Knowlton et al. 2010).

Valuing coral reef ecosystem services in a monetary way can be a useful tool to aid public decision-making. While valuation methods provide wildly different results (Cesar et al. 2003; Brander et al. 2007; Craig 2008; Laurans et al. 2013), using standardized methods, Cesar et al. (2003) have provided insight on the relative importance of four major ecosystem services (biodiversity maintenance, coastal protection, tourism, and fisheries) which were estimated to be worth US\$ 30 billion in net benefits in goods and services to world economies annually. The annual value of coastal protection from surging oceans (i.e. the cost of rebuilding if the protective function was lost) has been estimated at US\$ 9 billion (Cesar et al. 2003). Reef biodiversity, through research, conservation, and medical value, was estimated at US\$ 5.5 billion. Tourism was valued at US\$ 9.6 billion, almost twice the estimated value of reef fisheries (US\$ 5 billion) (Cesar et al. 2003), a finding also reflected by other valuation studies (Van Beukering et al. 2006; Craig 2008). For example, the US Commission on Ocean Policy (USCOP) indicates higher value of tourism over fisheries on non-coral reef industries, US\$ 60 to 31 million, respectively (Craig 2008; Spalding et al. 2017). Given the high growth of the coral reef tourism sector (Outra et al. 2016; Harvey and Naval 2016) that we detail further on in this chapter, new opportunities offered by tourism are underpinned by social, economic, and ecological trade-offs for scientists, managers, and fishers alike (Hicks et al. 2013).

\subsection{Impacts and Trends of Fisheries and Tourism}

\subsubsection{Impacts of Fisheries}

Although coral reef fisheries are a major source of local income and are socially and economically integral to coastal communities (McClanahan 1999; Cesar et al. 2003; Bruggemann et al. 2012; Fenner 2012), overfishing and destructive reef fisheries can jeopardize fish resources (Cesar et al. 2003; Fox 2004) and the resilience of entire reef ecosystems (Mumby et al. 2006; Fenner 2012; Bozec et al. 2016). Coral and their larvae, the seed stock of future coral reefs, can be outcompeted by macroalgae for space (Smith et al. 1981; Hunter and Evans 1995; Mumby et al. 2007; Doropoulos et al. 2017). Hence, overfishing of key func- 


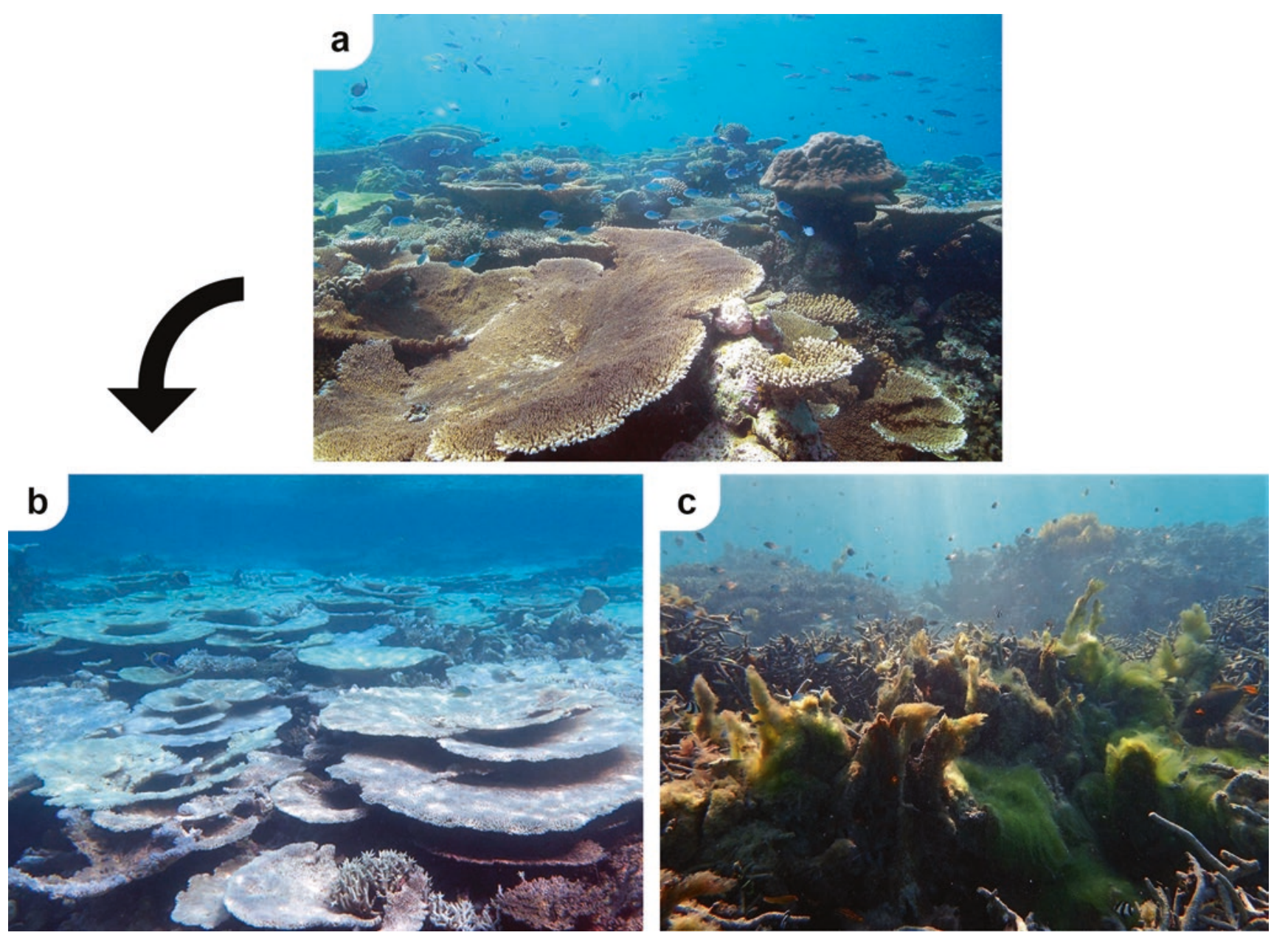

Fig. 13.1 Effects of the 2016 mass coral bleaching event in the central Maldives shown by the transition from healthy pre-bleaching coral reefs in the beginning of March (a) to a bleached coral state in the end

tional groups of reef organisms such as herbivorous fish can reduce grazing pressure on macroalgae, promoting phase shifts toward less productive coral-depleted ecosystem states (Mumby et al. 2016; Doropoulos et al. 2017). Overfishing of top predators can induce trophic cascades that also the coral reef ecosystem (Mumby et al. 2006). A study across the Northern Line Islands by Sandin et al. (2008) characterizes the systemic ecological effects of fishing on coral reefs. At Palmyra and Kingsman, uninhabited atolls where fishing pressure is low, top predators dominate the fish assemblage, the fish biomass pyramid is inverted, and coral coverage is very high. Conversely, at inhabited atolls Tabuaeran and Kiritimati where fishing pressure is high, there are far fewer large long-lived fish, a bottom-heavy food web, greater prevalence of coral disease, less coral recruitment, and generally more degraded reefs with higher algal overgrowth (Fig. 13.2) and lower coral coverage. Degraded overfished reefs are less productive for local fisheries causing conflicts for ever-limited resources (Bruggemann et al. 2012). of March (b) at a reef crest in eastern Baa Atoll and finally to a postbleaching macroalgal colonization at a propagation project on the reef flat of the nearby North Male Atoll (c). Photo credit: Stephen Bergacker

To understand long-term overfishing trends that underpin trade-offs affecting coral reef fishers, we conducted a systematic literature review in Web of Science ${ }^{\circledR}$ using the following study topic search string: ("coral reef" or "coral reefs") and ("fisheries" or "fishery" or "fishing") and ("historic" or "reconstruction" or "reconstruct"). Of the 250 results, 12 studies met our two relevance criteria, namely, a main focus on coral reef fisheries and a reconstruction period $<25$ years. A key reconstruction by Zeller et al. (2015) that did not show in the search results was also included for this review.

As many coral reef fisheries lack historic data on catch size, catch composition, fishing gear use or catch per unit effort (CPUE) (Sadovy de Mitcheson et al. 2008) alternative methods for estimating fisheries trends are useful. Traditional ecological knowledge of fishing communities can be used to understand prominent ecological changes (Lavides et al. 2010), but such assessments are limited to the period of living memory, approximately 50 years pre-publication (Golden et al. 2014). By combining anecdotal evidence from semi- 

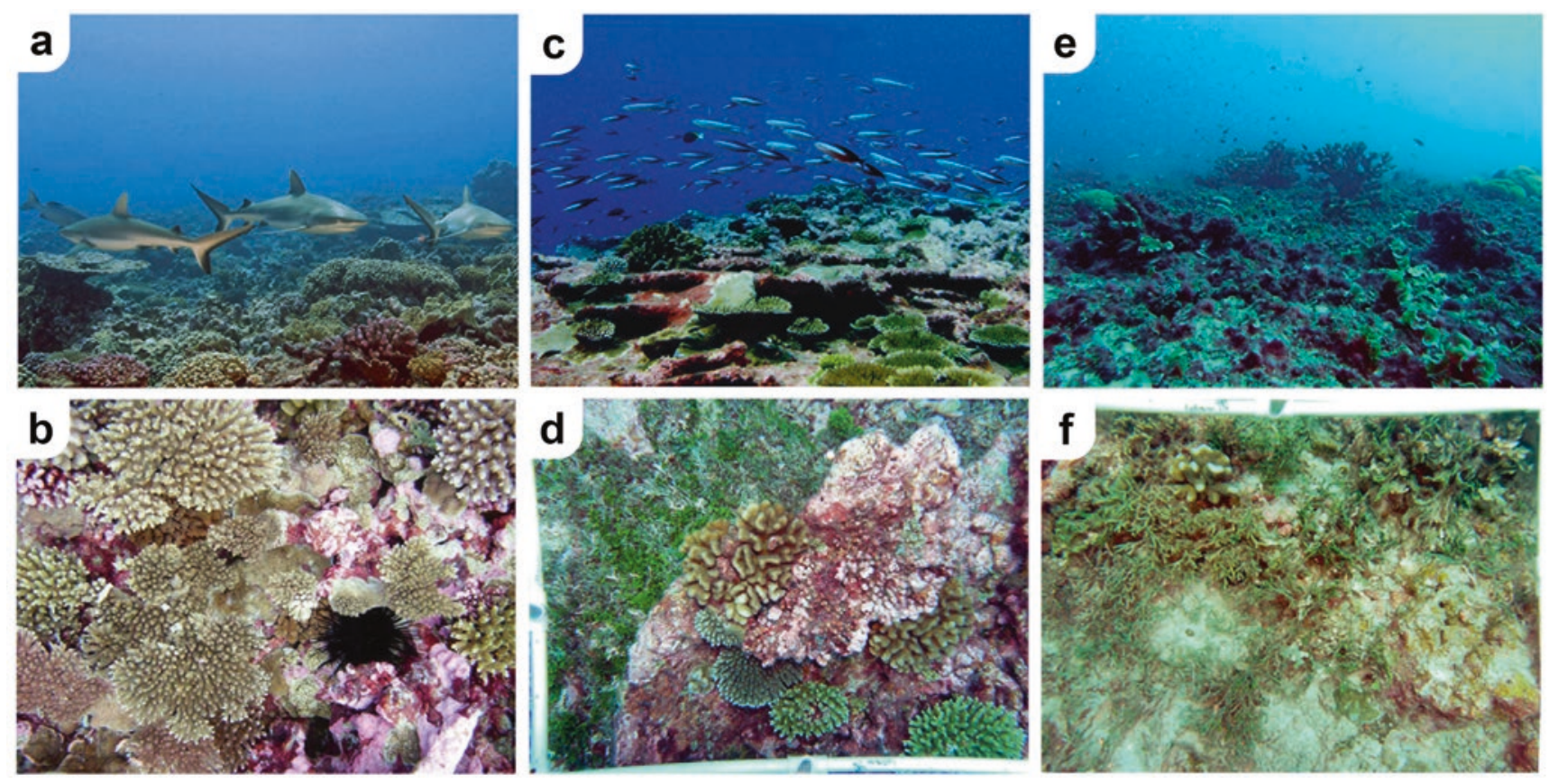

Fig. 13.2 General fore reef habitats with characteristic fish communities (top row: a, c, e) and representative $0.5 \mathrm{~m}^{2}$ photos of the reef substrate (bottom row: b, d, e) at Kingsman $(\mathbf{a}, \mathbf{b})$, Tabuaeran $(\mathbf{c}, \mathbf{d})$, and Kiritimati (e, f), Northern Line Islands, showing a degradation gradi-

structured interviews with available fisheries catch or human population data we can gain insight into temporal trends in fish biomass, catch size and composition, extinction date or CPUE (Hardt 2008; Claro et al. 2009; Lavides et al. 2010; Young et al. 2015; Samoilys et al. 2017). As shown in the schematic timeline (Table 13.1), the 1950s-1970s was a period characterized by high yields of large reef fish such as the herbivorous green bumphead parrotfish (Bolbometopon muricatum) (Lavides et al. 2016). By the 1980s-2000s, large schooling or spawning fish began to be replaced by small reef fish and invertebrates (Sadovy de Mitcheson et al. 2008).

\subsubsection{Anecdotal Reconstructions}

Due to observer bias, using semiquantitative anecdotal evidence for fisheries reconstructions is less reliable than using landing data. Golden et al. (2014) reported on changes to ecosystem dynamics and fish catch based on 22 semistructured interviews and a spearfishing survey. Only $11 \%$ of the recorded fish community composition was shared by both survey methods, and only three out of 14 species declines were reported by more than one respondent. The other $78 \%$ of species declines were reported by no more than one out of 22 respondents $(4.5 \%)$. Hence, these results may be heavily biased by individual experience or change in attitude, and thus should be interpreted with caution. A larger interview study by Lavides et al. (2010) $(\mathrm{n}=232)$ reported a similar proportion of rare species declines $(82 \%)$, also reported by less than $4.5 \%$ of the sample size ( $<11$ reports). ent - from reefs with numerous top predators and high coral coverage to reefs with few large predators, only small herbivorous fish, and dominated by fleshy macroalgae in place of coral. (Adapted from Sandin et al. (2008) with permission from PLoS One)

These studies exemplify the difficulty in detecting subtle ecological changes with nonquantitative or semiquantitative methodological techniques.

Fisheries reconstructions based on anecdotal evidence can be useful in identifying larger ecological perturbations and trends (Sadovy de Mitcheson et al. 2008; Lavides et al. 2016). Larger-scale dynamics are more likely to be detected by many people, increasing congruence between respondents. Lavides et al. (2016) identified declining trends in mean perceived CPUE for five species of reef fish, including the green bumphead parrotfish (B. muricatum) which declined $88 \%$ compared to 1950s' levels. As the largest of its kind, this widespread schooling fish was probably fished before the 1950s and is particularly vulnerable to heavy fishing with widespread declines in their once-common populations (Dulvy et al. 2004). Spawning aggregations for most reef fish occur in a short breeding season of up to 3 months making them highly vulnerable to fishing pressure. Through interview techniques Sadovy de Mitcheson et al. (2008) identified that most reef fish spawning aggregations in the Indo-Pacific and West Atlantic are in decline, with increasing aggregations only occurring where effective management strategies are in place.

\subsubsection{Quantitative Reconstructions}

Fisheries reconstructions using quantitative data mining of catch data provide more detailed information than those using anecdotal evidence; however, the spatial and temporal 
Table 13.1 Reconstructed reef fishery trends over the last century from 12 relevant publications, referring to the study and study country, target organisms (a, b, or c), net fish stock change throughout the reconstruction period, habitat ( $R$ reef, $C$ coastal, $P$ pelagic, or inshore), fishery type ( $S$ subsistence, $A$ artisanal, $I$ industrial), and the methodology

\begin{tabular}{|c|c|c|c|c|c|c|c|c|c|c|c|c|c|c|c|c|}
\hline Reference & Country & Change unit & Target organisms & $1900 \mathrm{~s}$ & $40 \mathrm{~s}$ & ‘50s & $60 \mathrm{~s}$ & $70 \mathrm{~s}$ & $80 \mathrm{~s}$ & 90 s & '00s & $10 \mathrm{~s}$ & $\begin{array}{c}\text { Net } \\
\text { change }\end{array}$ & Habitat & $\begin{array}{l}\text { Fishery } \\
\text { type }\end{array}$ & Methods \\
\hline $\begin{array}{l}\text { Cheung and } \\
\text { Sadovy (2004) }\end{array}$ & Hong Kong & $\begin{array}{c}\text { Biomass relative } \\
\text { to } 1950 \mathrm{~s} \\
\text { level }(\%)\end{array}$ & $\begin{array}{l}\text { a) Small benthic fish \& crustacean } \\
\text { b) Large demersal \& pelagic fish } \\
\text { c) Small pelagic fish; Cephalopods }\end{array}$ & $\begin{array}{l}- \\
- \\
-\end{array}$ & $\begin{array}{l}- \\
- \\
-\end{array}$ & & & & & & & $\begin{array}{l}- \\
- \\
-\end{array}$ & $\begin{array}{l}0 \\
- \\
+\end{array}$ & $\mathrm{R} ; \mathrm{C}$ & $A ; I$ & $\begin{array}{l}148 \text { semi-structured } \\
\text { interviews; } \\
\text { Catch data }\end{array}$ \\
\hline Claro et al. (2009) & Cuba & Catch (MT year ${ }^{-1}$ ) & $\begin{array}{l}\text { a) Epinephelus striatu } \\
\text { b) Lutjanus synagris } \\
\text { c) } 4 \text { other snapper species }\end{array}$ & $\begin{array}{l}- \\
- \\
-\end{array}$ & $\begin{array}{l}- \\
- \\
-\end{array}$ & & & & & & & & $\begin{array}{l}- \\
0\end{array}$ & $\mathrm{R}$ & $\mathrm{S} ; \mathrm{A} ; \mathrm{I}$ & Catch data \\
\hline Hardt (2008) & Jamaica & Abundance (\%) & a) All reef fish & & & & & & & & & & - & $\mathrm{R}$ & $\mathrm{S} ; \mathrm{A}$ & Literature 600AD+ \\
\hline $\begin{array}{c}\text { Lachica- } \\
\text { Alino et al. (2009) }\end{array}$ & Philippines & $\begin{array}{c}\text { Biomass } \\
\text { (no units given) }\end{array}$ & $\begin{array}{l}\text { a) Large, high-value fish } \\
\text { b) Small reef carnivore; Cephalopod }\end{array}$ & $\begin{array}{l}- \\
-\end{array}$ & $\begin{array}{l}- \\
-\end{array}$ & $\begin{array}{l}- \\
-\end{array}$ & & & & & & & + & $\mathrm{R} ; \mathrm{C}$ & 1 & $\begin{array}{c}\text { Catch data; } \\
\text { ECOSIM models }\end{array}$ \\
\hline Lavides et al. (2010) & Philippines & $\begin{array}{l}\text { Time of zero } \\
\text { catch }\end{array}$ & $\begin{array}{l}\text { a) Epinephelus anceolatus; }+8 \text { species } \\
\text { b) Thunnus albacares; }+6 \text { species } \\
\text { c) } 6 \text { other species }\end{array}$ & $\begin{array}{l}- \\
- \\
-\end{array}$ & $\begin{array}{l}- \\
- \\
-\end{array}$ & $\begin{array}{l}- \\
- \\
-\end{array}$ & & & & & & & $\begin{array}{l}- \\
- \\
\end{array}$ & $\mathrm{R}$ & $\mathrm{S} ; \mathrm{A}$ & $\begin{array}{l}232 \text { semi- } \\
\text { structured } \\
\text { interviews }\end{array}$ \\
\hline Lavides et al. (2016) & Philippines & $\begin{array}{l}\text { Perceived CPUE } \\
\quad\left(\mathrm{kg} \mathrm{day}^{-1}\right)\end{array}$ & $\begin{array}{l}\text { a) Bolbometopon muricatum } \\
\text { b) Epinephelus Anceolatus; }+2 \text { species } \\
\text { c) Alectis ciliaris }\end{array}$ & $\begin{array}{l}- \\
- \\
-\end{array}$ & $\begin{array}{l}- \\
- \\
-\end{array}$ & & & & & & & & $\dot{-}$ & $\mathrm{R}$ & $\mathrm{S} ; \mathrm{A} ; \mathrm{I}$ & $\begin{array}{l}2655 \text { semi- } \\
\text { structured Interviews }\end{array}$ \\
\hline $\begin{array}{l}\text { McClenachan and } \\
\text { Kittinger (2013) }\end{array}$ & $\begin{array}{l}\text { Hawaii; } \\
\text { Florida }\end{array}$ & $\begin{array}{l}\text { Net Catch } \\
\left(\mathrm{T} \mathrm{km}^{-2} \text { reef }\right)\end{array}$ & $\begin{array}{l}\text { a) All Hawaiian fish } \\
\text { b) All Florida Keys fish }\end{array}$ & & & & & & & & $\begin{array}{l}- \\
-\end{array}$ & $\begin{array}{l}- \\
-\end{array}$ & $\begin{array}{l}+ \\
+ \\
\end{array}$ & $\mathrm{R} ; \mathrm{C} ; \mathrm{P}$ & $\mathrm{S} ; \mathrm{A} ; \mathrm{I}$ & $\begin{array}{c}\text { Meta-analysis } \\
1300 \mathrm{AD}+\end{array}$ \\
\hline $\begin{array}{c}\text { Sadovy de } \\
\text { Mitcheson et al. } \\
(2008)\end{array}$ & $\begin{array}{l}\text { Indo-Pacific; } \\
\text { West Atlantic }\end{array}$ & $\begin{array}{l}\text { Catch }\left(\mathrm{kg} \mathrm{trip}^{-1}\right) \& \\
\text { Spawn- } \\
\text { aggregate status }\end{array}$ & $\begin{array}{l}\text { a) Palau grouper aggregations } \\
\text { b) Indo-Pacific aggregations } \\
\text { c) West Atlantic aggregations }\end{array}$ & $\begin{array}{l}- \\
\overline{-} \\
-\end{array}$ & $\begin{array}{l}- \\
- \\
-\end{array}$ & & & & & & & $\begin{array}{l}- \\
- \\
-\end{array}$ & $\begin{array}{l}- \\
- \\
-\end{array}$ & $\mathrm{R}$ & S; A & $\begin{array}{l}377 \text { semi- } \\
\text { structured } \\
\text { interviews }\end{array}$ \\
\hline $\begin{array}{c}\text { Samoilys et al. } \\
(2017)\end{array}$ & Kenya & CPUE $\left(\mathrm{kg}\right.$ trip $\left.^{-1}\right)$ & a) All fish catch & - & - & - & - & - & & & & - & - & $\mathrm{R}$ & A & Meta-analysis \\
\hline $\begin{array}{c}\text { Weijerman et al. } \\
(2016)\end{array}$ & Guam & $\begin{array}{l}\text { Catch }\left(\text { T year-1 }^{-1}\right) \\
\text { CPUE }\left(\mathrm{kg} \mathrm{hr}^{-1}\right)\end{array}$ & $\begin{array}{l}\text { a) All reef organisms } \\
\text { b) All reef organisms }\end{array}$ & $\begin{array}{l}- \\
-\end{array}$ & $\begin{array}{l}- \\
-\end{array}$ & $\begin{array}{l}- \\
-\end{array}$ & $\begin{array}{l}- \\
-\end{array}$ & $\begin{array}{l}- \\
-\end{array}$ & & & & & - & Inshore & $\mathrm{S} ; \mathrm{A}$ & $\begin{array}{l}\text { Creel survey; } \\
\text { Catch data }\end{array}$ \\
\hline Young et al. (2015) & Australia & $\begin{array}{l}\text { Reef catch }(\%) ; \\
\text { Fish weight }(\mathrm{kg})\end{array}$ & $\begin{array}{l}\text { a) Reef fish } \\
\text { b) Reef fish }\end{array}$ & $\begin{array}{l}- \\
-\end{array}$ & $\begin{array}{ll}- \\
-\end{array}$ & & & & $\begin{array}{l}- \\
-\end{array}$ & & & $\begin{array}{l}- \\
-\end{array}$ & \pm & $R ; C ; P$ & $\mathrm{R}$ & $\begin{array}{c}\text { Meta-analysis, } \\
\text { magazine reports }\end{array}$ \\
\hline Zeller et al. (2015) & Pacific Islands & Est. Catch $\left(\mathrm{T}_{\text {year }}{ }^{-1}\right)$ & a) All fish catch & - & & & & & & & & 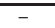 & + & $R ; C ; P$ & $S ; A ; I$ & FAO Catch data \\
\hline
\end{tabular}

Cell color indicates the sign of net fisheries trends in that period, either declining (dark red), stable (medium grey), or increasing (light blue). Note that different units are used in each study. Fisheries trends of Cheung and Sadovy (2004), Lachica-Alino et al. (2009), McClenachan and Kittinger (2013), and Zeller et al. (2015) use combined habitats analyses that mask underlying reef-specific fisheries trends

availability of catch data is predominantly limited to the most commonly fished areas in more recent times (Pauly 1995; Cheung and Sadovy 2004). Declines in reef fisheries since the 1950s are commonplace (Claro et al. 2009; LachicaAlino et al. 2009; Weijerman et al. 2016); however more complex population dynamics between different groups of reef organisms obscure these net trends. In the Philippines, overfishing from trawl fisheries is shown to have reduced large high-value fish stocks. The concurrent effects to the food web structure of this marine system have resulted in increased biomass of small reef carnivores and cephalopods (Lachica-Alino et al. 2009). Similar results for Hong Kong were shown by Cheung and Sadovy (2004), where large fish species become replaced by small fish species and invertebrates. Bottom trawling fisheries will avoid reef areas as the nets, which are very expensive, can catch and tear on these hard substrates. In Guam, although there was a small increase in annual catch caused by successful spear fisheries in the late 1990s, the average catch from shore fisheries declined from $100 \mathrm{~T}_{\text {year }}^{-1}$ in $1985-1990$ to $37 \mathrm{~T}_{\text {year }}{ }^{-1}$ in 20072012. This was consistent with non-fisheries surveys which also show depleted shallow reef populations (Weijerman et al. 2016). Landings data allowed high-resolution assessments of six commercial reef fish in Cuba from 1955 to 2005. While four snapper species underwent no net change in catch biomass, Nassau grouper (Epinephelus striatus) and lane snapper (Lutjanus synagris) both experienced large declines in average catch over the 50-year study period: 1600 and $800 \mathrm{MT}_{\text {year }}{ }^{-1}$ to less than 100 and $450 \mathrm{MT}$ year $^{-1}$, respectively. In the early 1960s there were sharp increases in catch biomass for all commercial species mainly driven by the development of bottom trawl and fish trap fisheries (Claro et al. 2009). Coral reef fish population trends vary depending on a balance between biological life cycles and fishing gear and effort. Generally, schooling species such as green bumphead parrotfish and lane snapper or spawning species such as Nassau grouper are much more vulnerable to overfishing than cryptic reef organisms more inaccessible to fishers such as moray eel (Muraenidae) or octopus (Octopoda).

While large-scale studies are useful, they can often lose fine-scale resolution. A recent study on national catch reconstructions in 25 Pacific island nations and territories showed increasing fishing trends throughout the Pacific from 1950 to 2010 (Zeller et al. 2015), while a reconstruction of Hawaiian and Florida Keys fisheries showed similar increasing trends (Table 13.1) (McClenachan and Kittinger 2013). The growth of huge pelagic fisheries over the last century masks the relatively smaller coral reef fishery declines reported in this synthesis. Historic reef fish declines reported by Hardt (2008) who focussed solely on reef fisheries was lost in the largescale studies by Zeller et al. (2015) and McClenachan and Kittinger (2013). In summary, coral reef fish declines are not ubiquitous but are the dominant global trend. Appropriate fisheries reconstructions using quantitative data mining rather than anecdotal evidence are useful for improving global fisheries catch datasets and hence inform fishing communities and governments on long-term trends lost in official records (Zeller et al. 2015). Economic pressures associated with such declining reef fisheries can influence the trade-offs fishers make when considering alternate sources of income such as tourism. 


\subsubsection{Tourism Trends}

Alongside fisheries declines and global population rise, the last half century has been characterized by the technical revolution with huge advances in transportation efficiency and cost, allowing economic shifts toward a globally multimilliondollar tourism industry (Craig 2008; Spalding et al. 2017). The number of visitors to Asia has increased more than $60 \%$ in the last 15 years with growth expected to reach $75 \%$ in the next decade (Outra et al. 2016). Of all global regions, the Asia-Pacific is experiencing the fastest growth in international tourism, closely followed by the Americas (Harvey and Naval 2016). This growth trend has been mirrored by the scuba diving industry which was once the fastest-growing recreational activity in the world (Tabata 1992), characterized by huge increases in the number of certified scuba divers since the 1970s (Fig. 13.3).

To understand the recent opportunities and impacts of coral reef tourism relevant to trade-offs made by coral reef resource users, we conducted a systematic literature search in Web of Science ${ }^{\circledR}$ targeting all studies on coral reefs since 2013. The search string combined the following three categories with and operators: (1) coral reef synonyms ("coral reefs" or "coral reef"), (2) current topics in coral reef ecology ("ecotourism" or "tourism" or "social ecological system" or "ecosystem-based management" or "ecosystem management" or "connectivity" or "replantation" or "keystone species" or "flagship species" or "invasive species" or "global warming" or "ocean acidification" or "climate change" or "fisheries"), and (3) a comprehensive list of coastal tropical countries from the United Nations (2018) and overseas territories from nationsonline.org, separated by or operators.

Based on the title and abstract, the 1043 search results were categorized by relevance to coral reefs, relevance to tourism, study country, and theme of main impact. Therefore, the resultant dataset of 36 tourism-related studies is a randomly sampled, spatially explicit representative of current research on coral reef tourism. This database was characterized by four major impact topics, referred to throughout this chapter and shown in Fig. 13.4 alongside the proportion of studies focused on scuba-diving compared to other tourism related topics. Socioeconomic and environmental impacts of tourism are discussed in this section, while socio-ecological and social perceptions and preferences are discussed in the next section.

\subsubsection{Economic Impacts}

Reef tourism provides major employment to coastal communities (Murray 2007; Lopes et al. 2015). The success of this industry rests on its high economic value (Cesar et al. 2003; Craig 2008), contributed to by on-reef tourism activities including diving, snorkeling, and glass-bottom boating, as well as reef-adjacent tourism attractions such as seafood, scenery, and beaches (Spalding et al. 2017). An extensive meta-analysis of 166 reef valuation studies from the $1980 \mathrm{~s}$ until 2007 revealed that the combination of diving, viewing, and snorkeling had the highest mean value (approx. US\$ 300), followed by diving alone (approx. US\$200), compared to snorkeling which was valued at less than $15 \%$ of mean

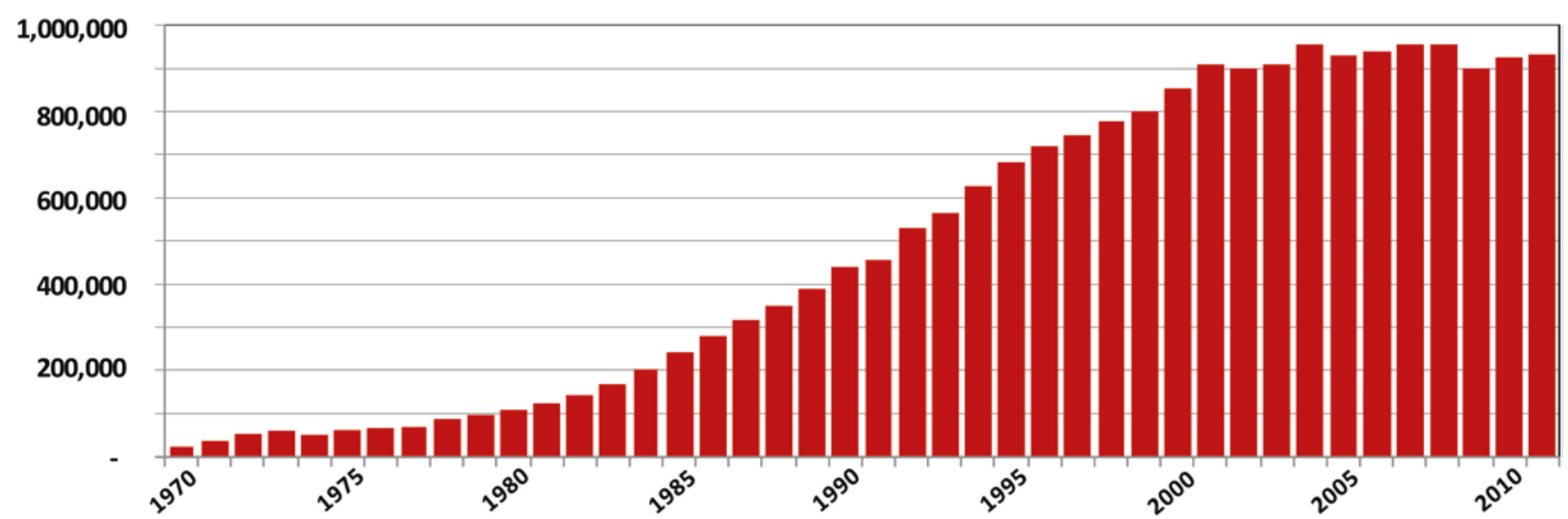

Represents total entry level and continuing education diving certifications for all PADI Offices combined. Divers may have multiple certifications.

Source: Global Certification \& Membership Statistics

Fig. 13.3 Number of PADI diving certifications obtained worldwide from 1970 to 2011. (Adapted from PADI global certification and membership statistics (http://www.padi.co.kr/images/Statistics-Kor.pdf accessed 21/05/2018) with permission from PADI Worldwide) 


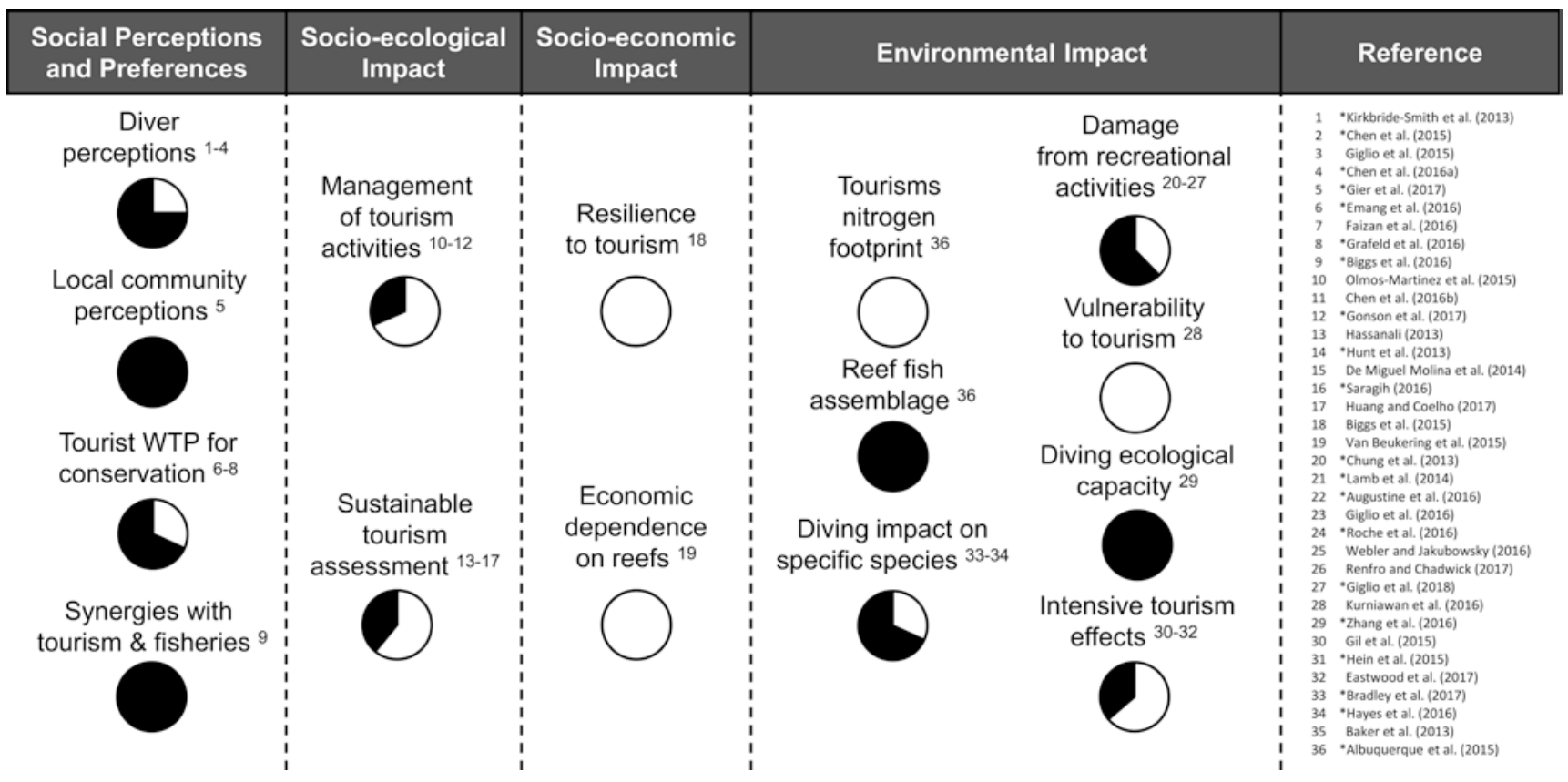

Fig. 13.4 From systematic review, a representative overview of 36 coral reef tourism studies since 2013, under four major impacts, and several sub-topics. Pie charts show the proportion of studies within

diving value (Fig. 13.5b, Brander et al. 2007). Diving and scenery are some of the most important activities for coral reef tourism (Hsui and Wang 2013). Brander et al. (2007) also showed that the economic value of coral reefs varies by global region (Fig. 13.5a). Coral reefs were valued highly across all global regions except the United States, with high median valuations for Australia and East Africa but lower median valuations for Southeast Asia and the Caribbean. As shown in our systematic review, the majority of coral reef tourism publications in the last 5 years have been conducted in the West Atlantic (Caribbean), Southeast Asia, and the Pacific (Fig. 13.5c), regions that have also undergone the largest growth in reef tourism over the past two decades (Harvey and Naval 2016; Outra et al. 2016). Therefore, as a growing industry in these regions, tourism may provide lucrative opportunities causing trade-offs for fishers and other employment sectors.

\subsubsection{Environmental Impacts}

Employee livelihoods are often heavily reliant on reef tourism and its ability to attract tourists to healthy coral reefs (Hunter et al. 2018). However, tourism-related threats such as enhanced sedimentation from changes in land use, loss of habitat due to land reclamation, expulsion of sewage and solid waste, and overuse by snorkelers and divers (Fig. 13.4) can contribute to reduced ecosystem resilience or phase each sub-topic relevant to diving (black), with diving-related studies marked $(*)$ in the references of this figure

shifts away from coral-dominated ecosystem states (Hawkins and Roberts 1994; Redding et al. 2013; Lamb et al. 2014; Renfro and Chadwick 2017), thereby jeopardizing tourismbased livelihoods (Smith et al. 1981).

Corals are controlled on a large scale by sedimentation. In areas further away from sources of runoff, with lower concentrations of sediment in overlying waters, reefs are generally more diverse, are better developed, and have higher framework accretion rates (Rogers 1990). Coral responses to moderate sedimentation include synchronous polyp pulsations, cleaning with tentacles or cilia, and concentration and excretion of sediment in mucus (Hubbard and Pocock 1972; Lirman and Manzello 2009), while complete covering by sediment leads to coral death within hours (Mayer 1918; Rogers 1990; Hunte and Wittenberg 1992). Phase shift theory suggests that the tipping point moving away from the coral-dominated state is not the same as the threshold on the return succession (Hughes et al. 2010). Therefore, fully degraded coral-dominated reefs can fail to recover even at much lower levels of sedimentation, due to repressed recruitment of sensitive juvenile corals (Hughes et al. 2010; Doropoulos et al. 2016). Enhanced sedimentation from tourism development has already caused substantial degradation of inshore reefs in the Egyptian Red Sea (Hawkins and Roberts 1994). 
Fig. 13.5 Coral reef valuations from the 1980s until 2007 by (a) global region and (b) recreational activity, showing mean and median value (bar and dot) with standard error bars (Brander et al. 2007). For comparison, the proportion of reef tourism studies published since 2013, derived from our systematic review dataset $(n=36)$, are shown for each global region (c). Sample size of each region/activity is shown in brackets. Regional labels differ between by our systematic review and Brander et al. (2007): Australia within Oceania, East Africa within Indian Ocean, US split between Hawaii in Pacific and Florida Keys in West Atlantic, Caribbean within West Atlantic. (Adapted from Brander et al. (2007) with permission from Elsevier) a

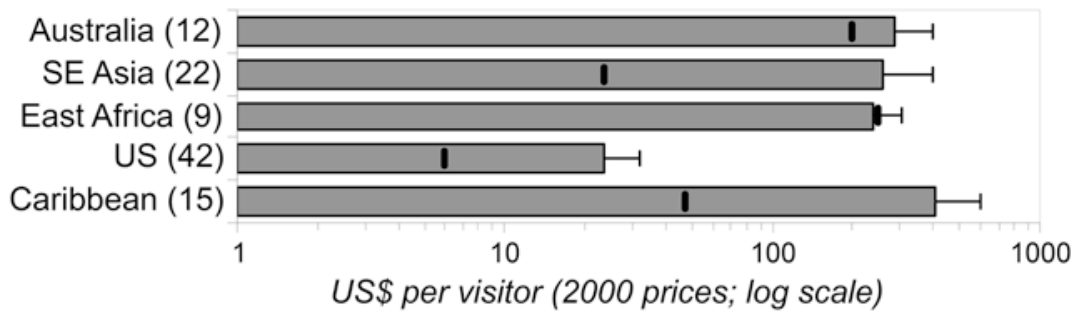

b

Coral reef values by recreational activity

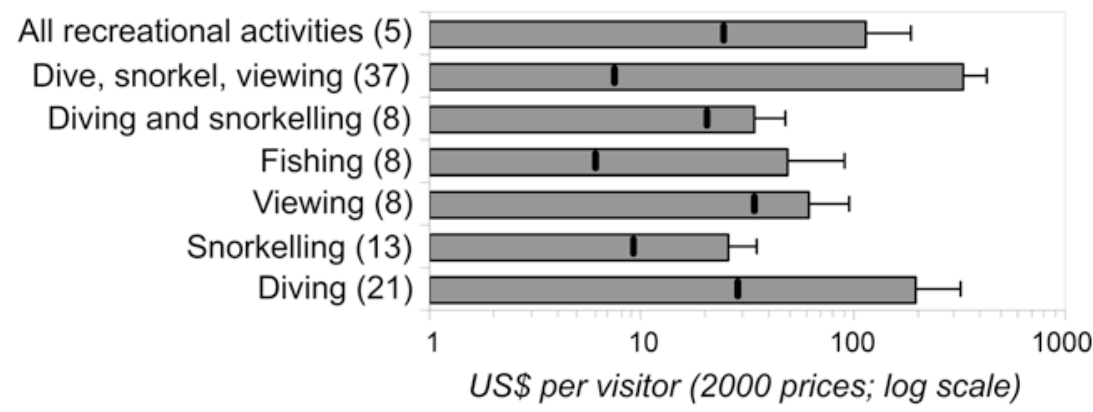

C

Coral reef tourism publications by region

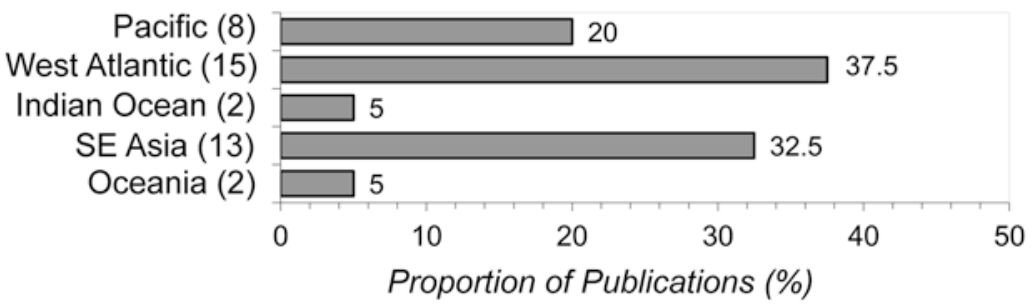

Discharge of untreated or partially treated effluent is a higher priority threat to coral reefs, with the potential to decrease coral coverage and promote overgrowth of other spatial benthic competitors such as macroalgae (Johannes 1975; Lapointe et al. 2005; Gil et al. 2015) or Zoantharia, soft-bodied benthic Cnidaria (Hunter and Evans 1995; Smith et al. 1981; Lapointe et al. 2010; Hernández-Delgado et al. 2008; Acosta et al. 2001; Lachs unpublished data). Field experiments and surveys show that nutrient enrichment and sewage pollution can jeopardize coral reef resilience by increasing the severity of diseases such as aspergillosis or yellow-band disease in common gorgonian sea fans (Gorgonia ventalina) and reef-building corals (Montastraea sp. and Porites sp.) (Bruno et al. 2003; Baker et al. 2007; Redding et al. 2013). Results of coral damage, disease advancement, and coral tissue loss (Fig. 13.6) are consistent from the Caribbean and Pacific Oceans. In Guam, the highest sewage signals were consistently measured at Tumon Bay which is the center of tourism, showing the specific risks of tourism-derived sewage on coral reef ecosystems (Redding et al. 2013). Given the global rise in population and tourism intensity, ecological impacts from sewage release should be closely monitored and considered by coral reef managers.

\subsection{Sector Overlap and Trade-Offs}

Managers and conservationists should consider the ecological trade-offs between tourism and fisheries industries. Overuse through heavy fishing, land-use change, or poor waste management can all lead to coral reef degradation, phase shifts, and even reef fishery collapse (Hawkins and Roberts 1994; Cesar et al. 2003; Mumby et al. 2006; Fenner 2012; Redding et al. 2013; Lamb et al. 2014; Bozec et al. 2016; Renfro and Chadwick 2017). While balancing the ecological trade-offs between coral reef fisheries and tourism, management strategies must also align with the social and economic interests of workers. Between industries, these interests are often in opposition, with regular disputes over spatial planning and zonation rights, varying education/skill set requirements and levels of salary/job security, and different world views and ecosystem service priorities (Brown 


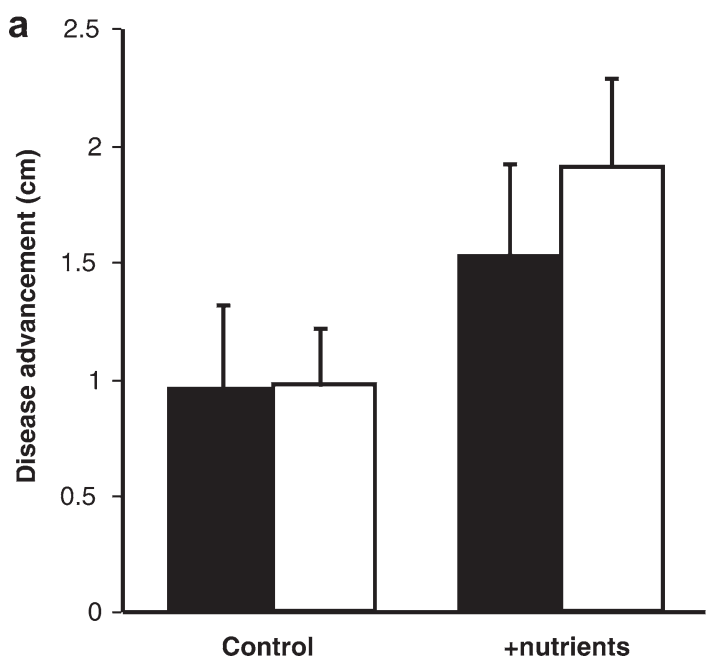

Fig. 13.6 Effect of experimental nutrient enrichment on (a) front advancement of yellow band disease and (b) coral tissue loss in the Caribbean reef building corals Montastraea annularis (white bars) and

et al. 1997; Fabinyi 2008; Hicks et al. 2013; Nejati et al. 2014; Lopes et al. 2015; de Andrade and de Oliveira Soares 2017; Hunter et al. 2018).

\subsubsection{Zoning Issues}

Inevitably, fishers and dive/snorkel tourism operators both need to work at coral reef sites. However, they cannot work alongside each other for obvious reasons. There is a potential gap in our current understanding of the perceptions of dive operators and fishers on the coexistence of their activities (Barker and Roberts 2004). Several recent studies agree that the motivations and principles of fishers and dive operators are distant, partially due to different educational backgrounds and ecosystem service priorities (Satria et al. 2004; Fabinyi 2008; de Andrade and de Oliveira Soares 2017). Despite this, both stakeholders agree on the importance of establishing marine protected areas (MPAs) (Fabinyi 2008; de Andrade and de Oliveira Soares 2017). Conflicts among these two sectors have been reported from developing countries such as Kenya and the Philippines (Hodgson and Dixon 1988; Samoilys et al. 2017). Divers and fishers repeatedly compete for space and resources in locations where zoning rules are not well established (Fabinyi 2008; de Andrade and de Oliveira Soares 2017), resulting in both parties blaming each other for negative ecosystem impacts in these areas. One hand, many large resort operators have conservation-oriented perceptions (Hein et al. 2018), promoting the protection of coral reefs to maintain the high biodiversity that attracts tourists, allowing them to enjoy greater underwater experiences. On the other hand, fishers defend all ecosystem services that involve exploitation opportunities and support their liveli-

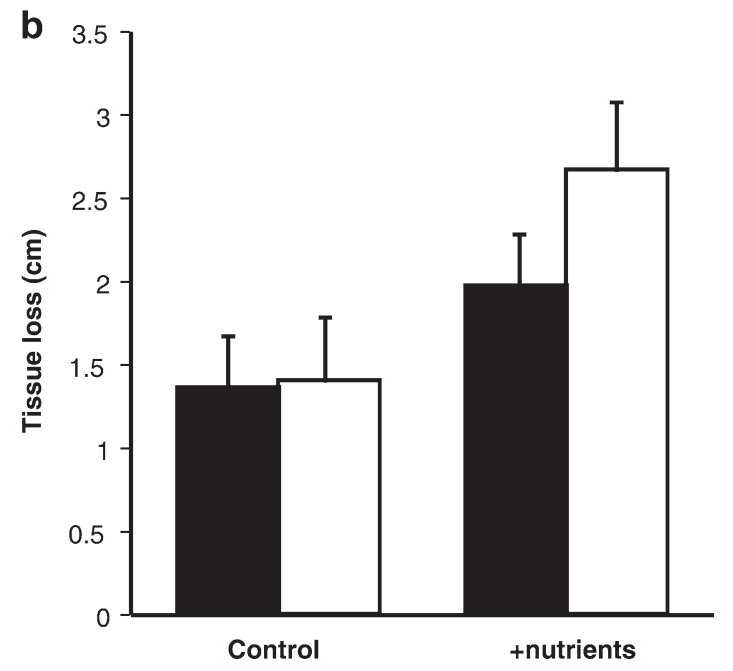

Montastraea franksii (black bars) during a 90-day in situ experiment (mean \pm standard error). (Adapted from Bruno et al. (2003), with permission from John Wiley and Sons)

hood (Fabinyi 2008; de Andrade and de Oliveira Soares 2017), especially those related to food security (Fisher et al. 2014). Accordingly, the role of MPAs in coral reef ecosystems may be less effective than they are designed to be. Fragile government regulations demonstrate that certain MPAs only exist on paper, enhancing zonation conflicts between tourism and traditional fishers (Satria et al. 2004).

\subsubsection{Livelihoods}

Despite the conflicts between tourism and fisheries industries, their coexistence is a persistent component of coral reef socioeconomic systems. As a seasonal industry, tourism cannot provide year-round employment, bringing with it a suite of social and economic challenges (Brown et al. 1997). Fisheries can provide an alternative livelihood in the tourist low season, causing a bidirectional flow of workers between both industries with seasonal cycles. However, the long term fisheries are relying on ever-dwindling fish stocks (Bruggemann et al. 2012; Zeller et al. 2015), influencing a residual flow of workers from fisheries to tourism where opportunities are more plentiful (Yacob et al. 2007). For instance, skippers can renovate and adapt their fishing boats to accommodate tourists or divers instead. Workers often transition from traditional livelihoods to tourism-based employment due to better wages and job security (Murray 2007; Lopes et al. 2015). Employee wages are consistently higher within the tourism industry than in fisheries (Nejati et al. 2014; Lopes et al. 2015; Hunter et al. 2018). For instance, in Malaysia, the employment of the local population on Redang Island is quite equally divided between tourism (50\%) and fisheries (45\%) (Nejati et al. 2014), but the 
Table 13.2 Literature summary of access value for coral reef MPAs since 1987

\begin{tabular}{|c|c|c|c|}
\hline Reference & Location & WTP US\$ & $\begin{array}{c}\text { Purpose of } \\
\text { valuation }\end{array}$ \\
\hline $\begin{array}{l}\text { Sloan } \\
(1987)\end{array}$ & $\begin{array}{c}\text { Heron Island, Great } \\
\text { Barrier Reef, } \\
\text { Australia }\end{array}$ & $\begin{array}{l}27 \text { person }^{-1} \\
\text { day }^{-1}\end{array}$ & Recreation \\
\hline $\begin{array}{l}\text { Dixon et al. } \\
\qquad(1995)\end{array}$ & $\begin{array}{c}\text { Bonaire National } \\
\text { Marine Park, } \\
\text { Caribbean }\end{array}$ & $\begin{array}{c}18 \text { diver }^{-1} \\
\text { year }^{-1}\end{array}$ & $\begin{array}{c}\text { Maintain dive } \\
\text { quality }\end{array}$ \\
\hline $\begin{array}{l}\text { Arin et al. } \\
(2002)\end{array}$ & $\begin{array}{l}\text { Anilo Marine } \\
\text { Sanctuary, } \\
\text { Philippines }\end{array}$ & $\begin{array}{c}3.70 \text { diver }^{-1} \\
\text { day }^{-1}\end{array}$ & $\begin{array}{c}\text { Support } \\
\text { marine } \\
\text { sanctuaries }\end{array}$ \\
\hline Yeo (2004) & $\begin{array}{c}\text { Pulau Payar Marine } \\
\text { Park, Malaysia }\end{array}$ & $\begin{array}{c}4.20 \text { person }^{-1} \\
\text { year }^{-1}\end{array}$ & Recreation \\
\hline $\begin{array}{l}\text { Asafu- } \\
\text { Adjaye et } \\
\text { al. (2008) }\end{array}$ & $\begin{array}{c}\text { Mu Ko Similan arine } \\
\text { Park, Thailand }\end{array}$ & $\begin{array}{c}\text { 27-63 diver }{ }^{-1} \\
\text { year }^{-1}\end{array}$ & $\begin{array}{l}\text { Diving in } \\
\text { MPAs }\end{array}$ \\
\hline $\begin{array}{c}\text { Yacob et al. } \\
\text { (2009) }\end{array}$ & $\begin{array}{l}\text { Redang Island } \\
\text { Marine Parks, } \\
\text { Malaysia }\end{array}$ & $\begin{array}{c}1.96-2.67 \\
\text { person }^{-1} \\
\text { year }^{-1}\end{array}$ & $\begin{array}{l}\text { Ecotourism } \\
\text { resources }\end{array}$ \\
\hline Thur (2010) & $\begin{array}{c}\text { Bonaire National } \\
\text { Marine Park, } \\
\text { Caribbean }\end{array}$ & $\begin{array}{c}\text { 61-134 diver }{ }^{-1} \\
\text { year }^{-1}\end{array}$ & $\begin{array}{l}\text { Diving in } \\
\text { MPAs }\end{array}$ \\
\hline $\begin{array}{l}\text { Mamat et } \\
\text { al. (2013) }\end{array}$ & $\begin{array}{l}\text { Pulau Redang } \\
\text { Marine Park, } \\
\text { Malaysia }\end{array}$ & $\begin{array}{c}2.73-7.20 \\
\text { person }^{-1} \text { visit }^{-1}\end{array}$ & $\begin{array}{c}\text { Environment } \\
\text { protection }\end{array}$ \\
\hline $\begin{array}{l}\text { Faizan et al. } \\
\qquad(2016)\end{array}$ & $\begin{array}{c}\text { Cape Rachado, } \\
\text { Malaysia }\end{array}$ & $\begin{array}{c}0.75^{*} \text { person }^{-1} \\
\text { visit }^{-1}\end{array}$ & $\begin{array}{c}\text { Coral reef } \\
\text { management }\end{array}$ \\
\hline $\begin{array}{l}\text { Grafeld et } \\
\text { al. (2016) }\end{array}$ & Guam & $\begin{array}{l}10 \text { person }^{-1} \\
\text { visit }^{-1}\end{array}$ & $\begin{array}{c}\text { Coastal and } \\
\text { watershed } \\
\text { management }\end{array}$ \\
\hline
\end{tabular}

Willingness to pay (WTP) units vary between studies, and values above ten are rounded to the nearest unit. Currency conversions were calculated using average annual exchange rates from the year of publication (www.ecb.europa.eu/stats, accessed 04 October 2018). The US\$ value by Faizan et al. (2016) (*) was converted from MYR. Adapted from Asafu-Adjaye and Tapsuwan (2008)

difference in monthly income is heavily in favor of tourism (MYR 500-700 or US\$ 106-149) over fisheries (MYR 350450 or US\$ 74-96) (Yacob et al. 2007) (Table 13.2 describes currency conversion methods). Tourism can provide higher wages up to double or triple that of fisheries in some regions (Lopes et al. 2015; Hunter et al. 2018).

\subsubsection{Ecosystem Service Priorities}

Fishers, tourism operators, scientists, and conservationists inherently value ecosystem services differently; however, there is an overlap in their priorities. Using a combination of interviews and network analysis in the Western Indian Ocean, Hicks et al. (2013) aimed to identify the key trade-offs in how fishers, managers, and scientists prioritize coral reef ecosystem services. While scientists and managers' ecosystem service priorities were more aligned, all three stakeholder groups agreed that fisheries, education and habitat are highly important services. However, The order of ecosystem priorities was different between stakeholder groups, whereby scientists agreed least with fishers leading to difficulties in balancing stakeholder value. Network analyses identified concerning trade-offs not immediately clear from the respondent's ecosystem service priorities - for fishers maximization of recreation and tourism was not possible without a loss in education and legacy of local cultural traditions. As the long-term shift from traditional livelihoods to tourism-based industry proceeds (Murray 2007; Yacob et al. 2007; Lopes et al. 2015) tourism is considered to threaten local culture by offering a tempting and profitable alternative to embracing local cultural heritage (Brown et al. 1997) resulting in a loss of culture, traditional knowledge and even language, especially in younger generations.

\subsection{Management Strategies: Benefits and Pitfalls}

\subsubsection{The Unmanaged Commons}

Long-standing fishing traditions, low tourism potential, and poor governance can cause mismanagement of reef resources and maximization of fishery intensity (Hardt 2008). The conceptual "tragedy of the unmanaged commons" is a problem described by Hardin (1968) where individual resource users aim to maximize their own benefit from an open access resource, resulting in the complete exhaustion of that resource. Open commons may benefit reef fishers temporarily, but long-term overfishing, depletion, or exhaustion of fish resources can lead to reduced ecological resilience, enhanced economic pressure, and concurrent social tension for subsistence income families that may be on the poverty line (Mumby et al. 2006; Walmsley et al. 2006; Fenner 2012; Teh and Sumaila 2013). Strategies to manage coral reef resources are necessary and vary widely. Top-down approaches by government, using ecosystem-based MPAs and fisheries embargos, are generally more suited to tourism-based coastal economies 
(Oracion et al. 2005; Yacob et al. 2007; Munga et al. 2012). Comparatively, bottom-up initiatives using collaborative management frameworks empower small-scale reef fishers and tourism operators to self-regulate (Cinner et al. 2012; Weeks and Jupiter 2013; Hunter et al. 2018). However, large coral reef tourism businesses or resorts can monopolize decision-making with strong financial backing and hence threaten co-management initiatives (Levine and Richmond 2014). Under the ever-changing world of international mobility, economic shifts, and climate-driven mass coral bleaching, adaptive co-management strategies supported by governments may provide the most resilient basis for management of coral reef resources (Cinner et al. 2012; Plummer et al. 2013; Weeks and Jupiter 2013).

\subsubsection{Ecosystem-Based Management}

To ensure a sustained resilience of coral reefs, management decisions must account for trends in ecosystem functionality (Bozec et al. 2016). On both ends of the spectrum between fishing intensity and tourism intensity, there are increased risks of ecological collapse and phase shifts away from the coral-dominated stable state (Van Beukering and Cesar 2004; Bozec et al. 2016). The importance of an ecological framework in decision-making is exemplified in the case of Bacuit Bay, Palawan, Philippines, in the 1970s (Hodgson and Dixon 1988). At this time Palawan was one of the last unspoiled areas of the Philippines with very low population density and plentiful marine and terrestrial resources. Throughout the 1980s and onward there was extensive immigration to Palawan, and unused resources became the subject of exploitation, with a $20 \%$ decline in forest area in 7 years alongside declines in yellowfin and skipjack tuna from intense fishery activities. Environmental degradation of the previously pristine coral reef and other marine ecosystems was further confounded by heavy siltation from forestry logging combined with dynamite and poison fisheries. An economic model was developed to test the effects of two management solutions: (1) to ban logging entirely in the bay's watershed or (2) to allow logging to continue as planned. The results of the economic analysis predicted a "reduction in gross revenue of more than US\$ 40 million over a 10-year period with continued logging of the Bacuit Bay watershed as compared with gross revenue given implementation of a logging ban" (Hodgson and Dixon 1988). This case study was resolved by the banning of logging in Palawan by the national government alongside the declaration of marine park status for the bay. The predictions about tourism growth were correct, however, overfishing has severely reduced populations of most high-value fish (Hodgson and Dixon 2000). This case highlights economic risks of coral reef degradation and the importance for policymakers and environmental managers to heed and incorporate scientific recommendations on ecological trends into ecosystem-based management policies.

Another ecosystem-based management approach is the use of MPAs. Theoretically, MPAs fulfil the requirements of conservation scientists, tourism managers, and artisanal fishers (Fabinyi 2008) by promoting conservation, management, and protection of natural resources and positively influencing fish diversity and abundance, including that of commercially valuable fish (Munga et al. 2012). However, marine park gazettements are often combined with legislation to ban coral reef fisheries or allow only minor fishing activities (Yacob et al. 2007; Lopes et al. 2015; Samoilys et al. 2017). Therefore, MPAs solve the tragedy of the common dilemma at the expense of resource users; not all stakeholders benefit equally from MPA management (Lopes et al. 2015; Samoilys et al. 2017). This is due to combinations of the following effects: competition between different resource users for the same resource, weak management regulations, ineffective governance, scarcity of funding, and nonproportionality of stakeholder representation in decision-making positions (McClanahan 1999; Tupper et al. 2015; Zimmerhackel et al. 2016). MPAs in the tropics are typically designed around coral reefs, where marine-based tourism plays an important and potentially disproportionately strong role in MPA management. Increasingly marine tourism causes conflict in local communities where traditional fishers who are not wellsuited to tourism are excluded from their livelihoods. Foreign tourists pay high prices that produce positive responses in some local groups but negative responses in other social groups such as artisanal fishers who do not benefit from tourism (Satria et al. 2004; Hicks et al. 2013). A lack of participative management and communication between stakeholders fosters divided perceptions and a lack of management policy uptake. Hence the drawback of ecosystem-based management is the uneven distribution of benefits.

\subsubsection{Co-management}

Collaborative management, also coined co-management, describes a decision-making system that combines top-down institutional frameworks and advice with bottom-up decision-making and empowerment of all local stakeholder groups (Roberts and Hawkins 2000; Cinner et al. 2012; Weeks and Jupiter 2013). Moving away from the top-down approach to management, such as in MPAs where some resources users are excluded, co-management employs community-scale local knowledge to work toward common goals (Levine and Richmond 2014). Increasing local involvement in MPA and resource use decision-making allows more balanced management solutions that fulfil the goals of tourism, fisheries, and other stakeholder groups, ensuring benefitsharing from reef resources (Roberts and Hawkins 2000; de Andrade and de Oliveira Soares 2017). When executed suc- 
cessfully with local institutions, co-management initiatives provide various social benefits and can promote more culturally relevant policies (Cinner et al. 2012; Levine and Richmond 2014). Governments that lack financial resources can pair with local partners to implement activities that would be otherwise unfeasible (Techera 2007). Various studies show that co-management can also influence the revitalization and sustainable use of marine resources maintaining livelihoods (Cinner et al. 2012; Weeks and Jupiter 2013).

Linking themes underpinning success include government and legislative support frameworks, government encouragement of local leadership, distinct community boundaries, unified village perceptions and representative leadership, the right to exclude outsiders from resource exploitation, and community-level enforcement of local laws (Levine and Richmond 2014). However, without these necessary components, co-management initiatives can fail and waste financial resources (Schultz et al. 2011; Cinner et al. 2012; Levine and Richmond 2014). This is shown by the Malagasy case described by Bruggemann et al. (2012). In Madagascar, coral reef resources are managed under legally recognized localscale governing bodies known as gelose (gestion locale sécurisée) and by local groups without legal status. This system is defined by a lack of government involvement or support. Resource use regulations are built locally using customary concepts including fady - activities that are taboo in certain areas, and dina - local laws. While this was a previously successful co-management system, recently, reefs have become overfished due to increased human migration from inland areas to the coast, increasing the number of fishers breaking fady and dina rules (Bruggemann et al. 2012). Co-management initiatives require some top-down government organization and influence to support the adaptive capacity of local institutions (Plummer et al. 2013; Weeks and Jupiter 2013; Levine and Richmond 2014; Hunter et al. 2018).

\subsubsection{Adaptive Co-management}

While co-management initiatives have extensive societal benefits, extensive field surveys around the Indian Ocean and Indo-Pacific suggest that co-management initiatives do not significantly improve fish biomass or ecosystem resilience, "indeed, people may collectively organize to exploit resources rather than to sustain them" (Cinner et al. 2012). Adaptive co-management may present a more progressive sustainable approach to resource use (Cinner et al. 2012; Weeks and Jupiter 2013; Hunter et al. 2018) that is relevant to the Anthropocene and recent unprecedented bleaching of coral reefs across the world (Hughes et al. 2017). This decisionmaking system combines the government-local format of comanagement with an additional evaluation and adaptation framework that includes environmental scientists in decision- making, using scientific advice to also promote long-term ecological sustainability (Weeks and Jupiter 2013).

\subsection{Tools to Manage Trade-Offs}

Due to complexity of multi-stakeholder decision-making and the wide range of factors affecting management success, sustainable adaptive co-management may seem an insurmountable challenge. However, various implementable management tools exist that can aid in balancing the trade-offs between fisheries, tourism, and other stakeholder groups and support coral reef socioeconomic systems (Stolk et al. 2007; Bozec et al. 2016; Faizan et al. 2016).

\subsubsection{Ecological Fisheries Regulations}

Combining ecosystem-based management and comanagement empowers local fishers while also managing for ecological sustainability (Hunter et al. 2018). Using scientific knowledge of ecosystem functioning to give fisheries recommendations can balance the ecological trade-offs of fisheries without excluding resource users (Sary et al. 1997; Bozec et al. 2016). From fish-exclusion mesocosms at the inner Great Barrier Reef, we know that 70-90\% reductions in herbivorous fish biomass can induce phase shifts away from the coral-dominated ecosystem state to a dense algal stable state with $>90 \%$ maximum algal coverage (Hughes et al. 2007). A fully calibrated fishery model developed by Bozec et al. (2016) suggests that harvesting parrotfish at maximum sustainable yield (40\% of exploitable biomass) can lead to long-term reductions $(75 \%)$ in unfished biomass similar to those shown in Hughes' fish-exclusion experiments. Given these results, phase shifts to algal-dominated ecosystem states are a realistic outcome from overfishing of grazing fish in coral reef ecosystems. Bozec et al. (2016) combined functional ecology and resilience theory to provide implementable management solutions to avoid ecosystem-breakdown scenarios; a minimum catch length of $>30 \mathrm{~cm}$ for parrotfish fisheries can provide a win-win scenario for fisheries and environmental interests in the short term. Fisheries yields are predicted to benefit due to a higher proportion of large size-class fish, while grazing pressure is maintained, leading to more resilient coral reefs. Such winwin scenarios have also been shown empirically. A fish trap exchange program which replaced small mesh-size traps with larger mesh-size traps in Discovery Bay, Jamaica led to a recovery of local reef fish populations alongside a increased catch of larger more valuable fish and increased CPUE (Sary et al. 1997). Therefore, small changes in fishing practice can lead to reductions in fishing pressure needed to allow recovery of reef fish populations and even increase 
catch. Such a strategy can be used to alleviate overfishing, without compromising local livelihoods and traditions.

\subsubsection{Iconic Species}

Shark, schooling fish, rays, and sea turtles are used by snorkel and dive operators throughout the world to promote tourism (Fisher et al. 2008; Vianna et al. 2012; Zimmerhackel et al. 2016). Diving tourism related to marine megafauna is a stable industry and has increased in popularity immensely around the world over the last decades (Higham and Lück 2008). While all divers have a strong preference to see charismatic megafauna, experienced divers have more interest in cryptic fauna (Giglio et al. 2015). Therefore, even coral reefs without megafauna have tourism potential, and adapting to diver preferences can increase consumer satisfaction and revenue (Giglio et al. 2015). Vianna et al. (2012) showed that sharkbased tourism and shark-diving were worth US\$ 18 million per year to the economy of Palau, 24 times that of total fisheries revenue. The chance to view sharks was the principal reason chosen by visitors to come to Palau. Thus, shark diving is the main economic activity, generating employment opportunities for boat drivers, hotels and restaurant workers, and civil engineers. Promoting iconic species tourism can help support biodiversity, improve tourism revenues, and provide local populations with alternate employment opportunities than fisheries (Vianna et al. 2012; Higham and Lück 2008).

\subsubsection{Tourist Fees}

Implementing marine park and beach access fees for leisure activities is another method to increase tourism revenue while subsidizing losses in fisheries revenue. We present a summary of the willingness to pay (WTP) of tourists visiting coral reefs over the last 30 years, adapted from Asafu-Adjaye and Tapsuwan (2008) (Table 13.2). From this summary, Faizan et al. (2016) found that local visitors and tourists had WTP for fees of MYR 3 (US\$ 0.65) for improving coral reef conservation in Malacca, Malaysia, which equates to over US\$ 150,000 per annum. In Guam, diver WTP for reef conservation could contribute over US\$ 8 million to annual revenues (Grafeld et al. 2016). As overseas divers' WTP is more than that of local divers, increasing prices for foreign divers is a likely way to increase revenues. Consequently, more visitors would not be needed to compensate for the cost of maintaining MPAs (Asafu-Adjaye and Tapsuwan 2008). While most marine park rangers are not part of the fisheries sector, the additional revenues from tourist fees could be used to employ fishers to assist rangers in patrolling, an option that has already shown large public interest from local fishing communities (Elliott et al. 2001).

\subsubsection{Artificial Reefs and Restoration}

Artificial reefs, restored reefs, and recent efforts to reskin artificial or dead corals with live coral are ecologically relevant techniques to promote reef resilience, support fish populations, provide employment, enhance tourism opportunities, and promote public awareness on coral reef loss (Grossman et al. 1997; Lirman and Schopmeyer 2016; Hein et al. 2018). Therefore, such projects have an applied use as a management tool, to offer alternative tourism-based employment to fishers (Lirman and Schopmeyer 2016). Although it is debated, evidence suggests that large communities of fish can be sustained on artificial reefs (Stolk et al. 2007; Smith et al. 2016). Artificial reefs were developed in the United States, Canada, Japan, Australia, and Europe (Coutin 2001) and were utilized up to 100 years ago by coastal fishing communities to boost fish catch around these structures (McGurrin et al. 1989). Improved fisheries from such aggregations have been well documented (McGurrin et al. 1989); however, it is not known if attracting and concentrating fish are effects of increased biomass or just a redistribution of biomass (Polovina and Sakai 1989; Polovina 1990; Stolk et al. 2007; Ajemian et al. 2015; Scott et al. 2015; Smith et al. 2016). Therefore, there is an urgent need for scientific assessments on the true effect of artificial reefs on fish stocks. SCUBA diving is the main commercial activity in coral reef areas (Hsui and Wang 2013). Recently, the use of artificial reefs has shifted toward tourism-based activities like diving, snorkeling, recreational fishing, nature preservation, and science (Seaman and Jensen 2000; Jakšić et al. 2013). It is important to consider the attitudes, perceptions, and satisfaction levels of scuba divers in the design of artificial reefs to guarantee good dives with a high level of biodiversity and wildlife photographic opportunities (Kirkbride-Smith et al. 2013). In Barbados, novice divers have a greater preference for artificial reef dive sites than experienced divers (Polak and Shasnar 2012). Artificial reefs can be used to reduce the physical damage of novice diving at sensitive natural sites while maintaining economic benefits by attracting an increasing number of advanced divers with specific diving requirements to less degraded natural reefs (Dearden et al. 2006; Kirkbride-Smith et al. 2013). Again, this shows how artificial reefs are an ecologically sensitive and enriching method of building resilience in MPAs.

\subsection{Recommendations for Management}

Weighing up the various costs and benefits of different industrial practices in coral reef ecosystems is a continual challenge. As resource rights, political situations and natural environments change new conflicts arise between conserva- 
tionists, scientists, fishers, tourism operators and local employees of other coastal industries. Proposed and implemented management strategies are rarely one-fits-all solutions. Management plans tend to push for consensus in identifying the most important ecosystem service and then manage for that service; however, this approach does not accommodate complex interactions between stakeholders' opinions or ecosystem service priorities.

We recommend holistic and effective resource use by developing adaptive co-management systems that combine topdown strategic frameworks with bottom-up decision-making. The tools and theories outlined in this review have been developed to promote the effectiveness of management actions, and some have good potential. Ecosystem-based fisheries modelling or long-term fisheries reconstructions can help direct fisheries regulations toward resilience, while the use of artificial reefs, tourist fees, and the promotion of iconic species can promote tourism and provide alternative livelihoods to fishers. Determining different stakeholder opinions and understanding trade-offs between different stakeholder priorities, as shown by Hicks et al. (2013), may lead to more integrated management decisions likely to represent the needs of local stakeholders proportionally. However, we point out that such co-management strategies should be framed by scientific ecological knowledge on the state and stability of coral reef ecosystems in the face of growing anthropogenic pressures. Hence, there is a need for extensive long-term ecological monitoring data. Comprehensive economic valuations of tourism and fisheries industries (e.g. those provided in the development of Palawan tourism in the Philippines. Hodgson and Dixon 1988, have the power to make real change and are a central component needed to convince governments to implement sustainable policies that promote the maintenance of healthy coral reef ecosystems, economies, and livelihoods.

Acknowledgments First, we would like to thank Sailee Sakhalkar, Farid Dahdouh-Guebas, Erin Lachs, and our reviewers for their critical readings of the manuscript and suggestions to layout, style, and structure. Their contributions were invaluable to the construction of this chapter. We would like to thank Seh Ling for her knowledgeable insights into the social dynamics of coastal coral reef communities in Peninsular Malaysia. We are thankful to Simon Jungblut, Farid Dahdouh-Guebas, and Zainudin Bachok for their general advice on the publication process. Last but not least, we would like to thank Stephen Bergacker for sharing the photographs of his humbling first-hand experience with coral bleaching in the Maldives.

\section{Appendix}

This article is related to the YOUMARES 9 conference session no. 16: "Tropical Marine Research Mosaic: combining small studies to reveal the bigger picture." The original Call for Abstracts and the abstracts of the presentations within this session can be found in the Appendix "Conference
Sessions and Abstracts", Chapter "12 Tropical Marine Research Mosaic: combining small studies to reveal the bigger picture", of this book.

\section{References}

Acosta A, Sammarco PW, Duarte LF (2001) Asexual reproduction in a zoanthid by fragmentation: the role of exogenous factors. Bull Mar Sci 68:363-381

Ajemian MJ, Wetz JJ, Shipley-Lozano B et al (2015) An analysis of artificial reef fish community structure along the northwestern Gulf of Mexico Shelf: potential impacts of 'rigs-to-reefs' programs. PLoS One 10:e0126345. https://doi.org/10.1371/journal.pone.0126354

Albuquerque T, Loiola M, Nunes J et al (2015) In situ effects of human disturbances on coral reef-fish assemblage structure: temporary and persisting changes are reflected as a result of intensive tourism. Mar Freshw Res 66:23-32. https://doi.org/10.1071/MF13185

Arin T, Kramer RA (2002) Divers' willingness to pay to visit marine sanctuaries: an exploratory study. Ocean Coast Manage 45:171-183

Asafu-Adjaye J, Tapsuwan S (2008) A contingent valuation study of scuba diving benefits: case study in mu Ko Similan marine National Park, Thailand. Tourism Manage 29:1122-1130. https://doi. org/10.1016/j.tourman.2008.02.005

Augustine S, Dearden P, Rollins R (2015) Are changing diver characteristics important for coral reef conservation? Aquat Conserv Mar Freshw Ecosyst 26:660-673. https://doi.org/10.1002/aqc.2574

Baker DM, MacAvoy SE, Kim K (2007) Relationship between water quality, $\delta 15 \mathrm{~N}$, and aspergillosis of Caribbean Sea fan corals. Mar Ecol Prog Ser 343:123-130. https://doi.org/10.3354/meps06937

Baker DM, Rodríguez-Martínez RE, Fogel ML (2013) Tourism's nitrogen footprint on a Mesoamerican coral reef. Coral Reefs 32:691699. https://doi.org/10.1007/s00338-013-1040-2

Barker NHL, Roberts CM (2004) Scuba diver behavior and the management of diving impacts on coral reefs. Biol Conserv 120:481-489

Bellwood DR, Hoey AS, Ackerman JL et al (2006) Coral bleaching, reef fish community phase shifts and the resilience of coral reefs. Glob Chang Biol 12:1587-1594. https://doi. org/10.1111/j.1365-2486.2006.01204.x

Bessell-Browne P, Stat M, Thomson D et al (2014) Coscinaraea marshae corals that have survived prolonged bleaching exhibit signs of increased heterotrophic feeding. Coral Reefs 33:795-804. https:// doi.org/10.1007/s00338-014-1156-z

Biggs D, Hicks CC, Cinner JE et al (2015) Marine tourism in the face of global changes: the resilience of enterprises to crises in Thailand and Australia. Ocean Coast Manage 105:65-74. https:// doi.org/10.1016/j.ocecoaman.2014.12.019

Biggs D, Amar F, Valdebenito A et al (2016) Synergies between naturebased tourism and sustainable use of marine resources: insights from dive tourism in territorial user rights for fisheries in Chile. PLoS One 11:e0148862. https://doi.org/10.1371/journal.pone.0148862

Bozec YM, O'Farrell S, Bruggemann JH et al (2016) Tradeoffs between fisheries harvest and the resilience of coral reefs. Proc Natl Acad Sci U S A 113:4536-4541. https://doi.org/10.1073/ pnas. 1601529113

Bradley D, Papastamatiou YP, Caselle JE (2017) No persistent behavioural effects on scuba diving on reef sharks. Mar Ecol Prog Ser 567:173-184. https://doi.org/10.3354/meps 12053

Brander LM, Van Beukering PJH, Cesar HSJ (2007) The recreational value of coral reefs: a meta-analysis. Ecol Econ 63:209-218. https:// doi.org/10.1016/j.ecolecon.2006.11.002

Brown K, Turner RK, Hameed H et al (1997) Environmental carrying capacity and tourism development in the Maldives and 
Nepal. Environ Conserv 24:316-325. https://doi.org/10.1017/ S0376892997000428

Bruggemann JH, Rodier M, Guillaume MMM et al (2012) Wicked social-ecological problems forcing unprecedented change on the latitudinal margins of coral reefs: the case of Southwest Madagascar. Ecol Soc 17:47. https://doi.org/10.5751/ES-05300-170447

Bruno JF, Petes LE, Harvell CD et al (2003) Nutrient enrichment can increase the severity of coral diseases. Ecol Lett 6:1056-1061. https://doi.org/10.1046/j.1461-0248.2003.00544.x

Cesar HSJ, Burke L, Pet-Soede L (2003) The economics of worldwide coral reef degradation. Cesar Environmental Economics Consulting, Arnhem, and World Wildlife Fund, Zeist, Dordrecht

Chen TC, Ying TC, Ku KC (2015) Advertising coral reefs with underwater panoramas: an application study on presenting information to prospective divers. J Mar Sci Tech 23:127-132. https://doi org/10.6119/JMST-014-0416-1

Chen TC, Ku KC, Chen CS (2016a) Collaborative adaptive management for bigfin squid applied to tourism-related activities in coastal waters of Northeast Taiwan. Ocean Coast Manage 119:208-216. https://doi.org/10.1016/j.ocecoaman.2015.10.010

Chen TC, Ho CT, Jan RQ (2016b) The differentiation of common species in a coral-reef fish assemblage for recreational scuba diving. Springer Plus 5:1758. https://doi.org/10.1186/s40064-016-3467-8

Cheung WWL, Sadovy Y (2004) Retrospective evaluation of datalimited fisheries: a case from Hong Kong. Rev Fish Biol Fisher 14:181-206. https://doi.org/10.1007/s11160-004-5422-y

Chung S, Au A, Qiu JW (2013) Understanding the underwater behaviour of scuba divers in Hong Kong. Environ Manag 51:824-837. https://doi.org/10.1007/s00267-013-0023-y

Cinner JE, McClanahan TR, MacNeil MA et al (2012) Comanagement of coral reef social-ecological systems. Proc Natl Acad Sci U S A 109:5219-5222. https://doi.org/10.1073/pnas.1121215109

Claro R, Sadovy Y, Mitcheson D et al (2009) Historical analysis of Cuban commercial fishing effort and the effects of management interventions on important reef fishes from 1960-2005. Fish Res 99:7-16. https://doi.org/10.1016/j.fishres.2009.04.004

Coutin PC (2001) Artificial reefs: applications in Victoria from a literature review. In: Marine and Freshwater Resources Institute, report No. 31, Queenscliff, Victoria

Craig RK (2008) Coral reefs, fishing, and tourism: tensions in U.S. ocean law and policy reform. Stanf Environ Law J 27:3-41

de Andrade AB, de Oliveira SM (2017) Offshore marine protected areas: divergent perceptions of divers and artisanal fishers. Mar Policy 76:107-113. https://doi.org/10.1016/j.marpol.2016.11.016

Dearden P, Bennet M, Rollins R (2006) Implications for coral reef conservation of diver specialization. Environ Conserv 33:353-363. https://doi.org/10.1017/S0376892906003419

de-Miguel-Molina B, de-Miguel-Molina M, Rumiche-Sosa ME (2014) Luxury sustainable tourism in small island developing states surrounded by coral reefs. Ocean Coast Manag 98:86-94. https://doi org/10.1016/j.ocecoaman.2014.06.017

Dixon JA, Scura LF, van't Hof T (1995) Ecology and microeconomics as 'joint products': the Bonaire Marine Park in the Caribbean. In: Perrings CA, Mäler KG, Folke $\mathrm{C}$ et al (eds) Biodiversity conservation, Ecology, economy and environment, vol 4. Springer, Dordrecht, pp 127-145

Doropoulos C, Roff G, Bozec YM et al (2016) Characterizing the ecological trade-offs throughout the early ontogeny of coral recruitment. Ecol Monogr 86:20-44. https://doi.org/10.1890/15-0668.1

Doropoulos C, Roff G, Visser MS et al (2017) Sensitivity of coral recruitment to subtle shifts in early community succession. Ecology 98:304-314. https://doi.org/10.1002/ecy.1663

Dulvy NK, Polunin NV, Mill AC et al (2004) Size structural change in lightly exploited coral reef fish communities: evidence for weak indirect effects. Can J Fish Aquat Sci 61:466-475. https://doi. org/10.1139/f03-169
Eastwood EK, Clary DG, Melnick DJ (2017) Coral reef health and management on the verge of a tourism boom: a case study from Miches, Dominican Republic. Ocean Coast Manage 138:192-204. https://doi.org/10.1016/j.ocecoaman.2017.01.023

Elliott G, Mitchell B, Wiltshire B et al (2001) Community participation in marine protected area management Wakatobi National Park, Sulawesi, Indonesia. Coast Manag 29:295-316. https://doi. org/10.1080/089207501750475118

Emang D, Lundhede TH, Thorsen BJ (2016) Funding conservation through use and potentials for price discrimination among scuba divers at Sipadan, Malaysia. J Environ Manage 182:436-445. https://doi.org/10.1016/j.jenvman.2016.07.033

Fabinyi M (2008) Dive tourism, fishing and marine protected areas in the Calamianes Islands, Philippines. Mar Policy 32:898-904. https://doi.org/10.1016/j.marpol.2008.01.004

Faizan M, Sasekumar A, Chenayah S (2016) Estimation of local tourists willingness to pay. Reg Stud Mar Sci 7:142-149. https://doi. org/10.1016/j.rsma.2016.06.005

Fenner D (2012) Challenges for managing fisheries on diverse coral reefs. Diversity 4:105-160. https://doi.org/10.3390/d4010105

Ferrario F, Beck MW, Storlazzi CD et al (2014) The effectiveness of coral reefs for coastal hazard risk reduction and adaptation. Nat Commun 5:3794. https://doi.org/10.1038/ncomms4794

Fisher JB, Nawaz R, Fauzi R et al (2008) Balancing water, religion and tourism on Redang Island, Malaysia. Environ Res Lett 3:024005. https://doi.org/10.1088/1748-9326/3/2/024005

Fisher JA, Patenaude G, Giri J et al (2014) Understanding the relationship between ecosystems services and poverty alleviation: a conceptual framework. Ecosyst Serv 7:34-45. https://doi.org/10.1016/j. ecoser.2013.08.002

Fox HE (2004) Coral recruitment in blasted and unblasted sites in Indonesia: assessing rehabilitation potential. Mar Ecol Prog Ser 269:131-139. https://doi.org/10.3354/meps269131

Gier L, Christie P, Amolo R (2017) Community perceptions of scuba dive tourism development in Bien Unido, Bohol Island, Philippines. J Coast Conserv 21:153-166. https://doi.org/10.1007/ s11852-016-0484-2

Giglio VJ, Luiz OJ, Schiavetti A (2015) Marine life preferences and perceptions among recreational divers in Brazilian coral reefs. Tour Manag 51:49-57. https://doi.org/10.1016/j.tourman.2015.04.006

Giglio VJ, Luiz OJ, Schiavetti A (2016) Recreational diver behaviour and contacts with benthic organisms in the Abrolhos National Marine Park, Brazil. J Environ Manag 57:637-648. https://doi. org/10.1007/s00267-015-0628-4

Giglio VJ, Luiz OJ, Barbosa M et al (2018) Behaviour of recreational spearfishers and its impacts on corals. Aquat Conserv Mar Freshw Ecosyst 28:167-174. https://doi.org/10.1002/aqc.2797

Gil MA, Renfro B, Figueroa-Zavala B et al (2015) Rapid tourism growth and declining coral reefs in Akumal, Mexico. Mar Biol 162:2225-2233. https://doi.org/10.1007/s00227-015-2748-z

Golden AS, Naisilsisili W, Ligairi I et al (2014) Combining natural history collections with fisher knowledge for community-based conservation in Fiji. PLoS One 9:e98036. https://doi.org/10.1371/ journal.pone.0098036

Gonson C, Pelletier D, Alban F et al (2017) Influence of settings management and protection status on recreational issues and pressures in marine protected areas. J Environ Manag 200:170-185. https:// doi.org/10.1016/j.jenvman.2017.05.051

Grafeld S, Oleson K, Barnes M et al (2016) Divers' willingness to pay for improved coral reef conditions in Guam: an untapped source of funding for management and conservation? Ecol Econ 128:202213. https://doi.org/10.1016/j.ecolecon.2016.05.005

Grossman GD, Jones GP, Seaman WJ Jr (1997) Do artificial reefs increase regional fish production? A review of existing data. Fisheries 22:1723. https://doi.org/10.1577/1548-8446(1997)022<0017:DARIRF>2 $.0 . \mathrm{CO} ; 2$ 
Hardin G (1968) The tragedy of the commons. Science 162:1243-1248 https://doi.org/10.1126/science.162.3859.1243

Hardt MJ (2008) Lessons from the past: the collapse of Jamaican coral reefs. Fish Fish 10:143-158. https://doi. org/10.1111/j.1467-2979.2008.00308.x

Harvey C, Naval J (2016) Green fins - a proven approach for managing marine tourism industry growth. Visit Econ Bull. Available at: https://pata.org/store/wp-content/uploads/2016/11/PATA-VEBulletin_November-2016.pdf. Accessed 18 May 2018

Hassanali K (2013) Towards sustainable tourism: the need to integrate conservation and development using the Buccoo reef Marine Park, Tobago, West Indies. Nat Resour Forum 37:90-102. https://doi. org/10.1111/1477-8947.12004

Hawkins JP, Roberts CM (1994) The growth of coastal tourism in the Red Sea: present and future effects on coral reefs. Ambio 23:503508. https://doi.org/10.1016/0006-3207(96)83261-7

Hayes CT, Baumbach DS, Juma D et al (2016) Impacts of recreational diving on hawksbill sea turtle (Eretmochelys imbricata) behaviour in a marine protected area. J Sustain Tour 25:79-95. https://doi.org/ 10.1080/09669582.2016.1174246

Hein MY, Lamb JB, Scott C et al (2015) Assessing baseline levels of coral health in a newly established marine protected area in a global scuba diving hotspot. Mar Environ Res 103:56-65. https://doi. org/10.1016/j.marenvres.2014.11.008

Hein MY, Couture F, Scott CM (2018) Ecotourism and coral reef restoration. In: Prideaux B, Pabel A (eds) Coral reefs: tourism, conservation and management. Earthscan Oceans, Oxford

Hernández-Delgado EA, Sandoz B, Bonkosky M et al (2008) Impacts of non-point source sewage pollution on Elkhorn coral, Acropora palmata (Lamarck), assemblages of the southwestern Puerto Rico shelf. In: Proceedings of the 11th international coral reef symposium, Fort Lauderdale, Florida, 7-11 July 2018

Heron SF, Maynard JA, Van Hooidonk R et al (2016) Warming trends and bleaching stress of the world's coral reefs 1985-2012. Sci Rep 6:38402. https://doi.org/10.1038/srep38402

Hicks CC, Graham NAJ, Cinner JE (2013) Synergies and tradeoffs in how managers, scientists, and fishers value coral reef ecosystem services. Glob Environ Chang 23:1444-1453. https://doi. org/10.1016/j.gloenvcha.2013.07.028

Higham JES, Lück M (2008) Marine wildlife and tourism management: in search of scientific approaches to sustainability. In: Higham JES, Lück M (eds) Marine wildlife and tourism management: insights from the natural and social sciences. CAB International, Wallingford, pp 1-16

Hodgson G, Dixon JA (1988) Logging versus fisheries and tourism in Palawan: an environmental and economic analysis. Occasional papers of the East-West Environment and Policy Institute (Paper no 7). East-West Center, Honolulu

Hodgson G, Dixon J (2000) El Nido revisited: ecotourism, logging and fisheries. In: Cesar HSJ (ed) Collected essays on the economics of coral reefs. Cordio, Kalmar, pp 55-68

Hsui CY, Wang CC (2013) Synergy between fractal dimensions and lacunarity index in design of artificial habitat for alternative Scuba diving site. Ecol Eng 53:6-14. https://doi.org/10.1016/j. ecoleng.2013.01.014

Huang Y, Coelho VR (2017) Sustainability performance assessment focusing on coral reef protection by the tourism industry in the coral triangle region. Tour Manag 59:510-527. https://doi.org/10.1016/j. tourman.2016.09.008

Hubbard JAEB, Pocock YP (1972) Sediment rejection by recent scleractinian corals: a key to palaeo-environmental reconstruction. Geol Rundsch 61:598-626. https://doi.org/10.1007/BF01896337

Hughes TP, Rodrigues MJ, Bellwood DR et al (2007) Phase shifts, herbivory, and the resilience of coral reefs to climate change. Curr Biol 17:360-365. https://doi.org/10.1016/j.cub.2006.12.049
Hughes TP, Graham NAJ, Jackson JBC et al (2010) Rising to the challenge of sustaining coral reef resilience. Trends Ecol Evol 25:633642. https://doi.org/10.1016/j.tree.2010.07.011

Hughes TP, Kerry JT, Álvarez-Noriega M et al (2017) Global warming and recurrent mass bleaching of corals. Nature 543:373-377. https://doi.org/10.1038/nature21707

Hunt CV, Harvey JJ, Miller A et al (2013) The green fins approach for monitoring and promoting environmentally sustainable scuba diving operations in South East Asia. Ocean Coast Manag 78:35-44. https://doi.org/10.1016/j.ocecoaman.2013.03.004

Hunte W, Wittenberg M (1992) Effects of eutrophication and sedimentation on juvenile corals. Mar Biol 112:131-138. https://doi. org/10.1007/BF00349736

Hunter CL, Evans CW (1995) Coral reefs in Kaneohe Bay, Hawaii: two centuries of western influence and two decades of data. Bull Mar Sci 57:501-515

Hunter CE, Lauer M, Levine A et al (2018) Maneuvering towards adaptive co-management in a coral reef fishery. Mar Policy 98:77-84. https://doi.org/10.1016/j.marpol.2018.09.016

Jackson JBC, Donovan MK, Cramer KL et al (2014) Status and trends of Caribbean coral reefs 1970-2012. Global Coral Reef Monitoring Network, IUCN, Gland

Jakšić S, Stamenković I, Đorđević J (2013) Impacts of artificial reefs and diving tourism. Turizam 17:155-165

Johannes RE (1975) Pollution and degradation of coral reef communities. In: Ferguson Wood EJ, Johannes RE (eds) Tropical marine pollution. Oceanogr Ser 12:13-51

Kelman D, Kashman Y, Rosenberg E et al (2001) Antimicrobial activity of the reef sponge Amphimedon viridis from the Red Sea: evidence for selective toxicity. Aquat Microb Ecol 24:9-16. https://doi. org/10.3354/ame024009

Kirkbride-Smith AE, Wheeler PM, Johnson ML (2013) The relationship between diver experience levels and perceptions of attractiveness of artificial reefs - examination of a potential management tool. PLoS One 8:e68899. https://doi.org/10.1371/journal.pone.0068899

Knowlton N, Brainard RE, Fisher R et al (2010) Coral reef biodiversity. In: McIntyre AD (ed) Life in the world's oceans. Blackwell, pp 65-77. https://doi.org/10.1002/9781444325508.ch4

Kurniawan F, Adrianto L, Bengen DG et al (2016) Vulnerability assessment of small islands to tourism: the case of the Marine Tourism Park of the Gili Matra Islands, Indonesia. Glob Ecol Conserv 6:308-326. https://doi.org/10.1016/j.gecco.2016.04.001

Lachica-Alino L, David LT, Wolff M et al (2009) Distributional patterns, habitat overlap and trophic interactions of species caught by trawling in the Ragay Gulf, Philippines. Philipp Agric Sci 92:46-65

Lamb JB, True JD, Piromvaragorn S et al (2014) Scuba diving damage and intensity of tourist activities increases coral disease prevalence. Biol Conserv 178:88-96. https://doi.org/10.1016/j. biocon.2014.06.027

Lapointe BE, Barile PJ, Littler MM et al (2005) Macroalgal blooms on southeast Florida coral reefs II. Cross-shelf discrimination of nitrogen sources indicates widespread assimilation of sewage nitrogen. Harmful Algae 4:1106-1122. https://doi.org/10.1016/j. hal.2005.06.002

Lapointe BE, Langton R, Bedford BJ et al (2010) Land-based nutrient enrichment of the Buccoo Reef complex and fringing coral reefs of Tobago, West Indies. Mar Pollut Bull 60:334-343. https://doi. org/10.1016/j.marpolbul.2009.10.020

Laurans Y, Pascal N, Binet T et al (2013) Economic valuation of ecosystem services from coral reefs in the South Pacific: taking stock of recent experience. J Environ Manag 116:135-144. https://doi. org/10.1016/j.jenvman.2012.11.031

Lavides MN, Polunin NVC, Stead SM et al (2010) Finfish disappearances around Bohol, Philippines inferred from traditional. Environ Conserv 36:235-244. https://doi.org/10.1017/S0376892909990385 
Lavides MN, Molina EPV, de la Rosa Jr. GE et al (2016) Patterns of coral-reef finfish species disappearances inferred from fishers' knowledge in global epicentre of marine shorefish diversity. PLoS One 11:e0155752. doi:https://doi.org/10.1371/journal. pone. 0155752

Levine AS, Richmond LS (2014) Examining enabling conditions for community-based fisheries comanagement: comparing efforts in Hawai'i and American Samoa. Ecol Soc 19:24. https://doi. org/10.5751/ES-06191-190124

Lirman D, Manzello D (2009) Patterns of resistance and resilience of the stress-tolerant coral Siderastrea radians (Pallas) to sub-optimal salinity and sediment burial. J Exp Mar Biol Ecol 369:72-77. https://doi.org/10.1016/j.jembe.2008.10.024

Lirman D, Schopmeyer S (2016) Ecological solutions to reef degradation: optimizing coral reef restoration in the Caribbean and Western Atlantic. PeerJ 4:e2597. https://doi.org/10.7717/peerj.2597

Lopes PFM, Pacheco S, Clauzet M et al (2015) Fisheries, tourism, and marine protected areas: conflicting or synergistic interactions? Ecosyst Serv 16:333-340. https://doi.org/10.1016/j. ecoser.2014.12.003

Mamat MP, Yacob MR, Radam A et al (2013) Willingness to pay for protecting natural environments in Pulau Redang Marine Park, Malaysia. Afr J Bus Manage 1:2420-2426. https://doi.org/10.5897/ AJBM10.752

Mayer AG (1918) Ecology of the Murray Island coral reef. Carnegie lnst Wash Pub 213:3-48

McClanahan TR (1999) Is there a future for coral reef parks in poor tropical countries? Coral Reefs 18:321-325. https://doi.org/10.1007/ s003380050205

McClenachan L, Kittinger JN (2013) Multicentury trends and the sustainability of coral reef fisheries in Hawai' $i$ and Florida. Fish Fish 14:239-255. https://doi.org/10.1111/j.1467-2979.2012.00465.x

McGurrin JM, Stone RB, Sousa RJ (1989) Profiling United States artificial reef development. Bull Mar Sci 44:1004-1013

Mumby PJ, Dahlgren CP, Harborne AR et al (2006) Fishing, trophic cascades, and the process of grazing on coral reefs. Science 311:98101. https://doi.org/10.1126/science. 1121129

Mumby PJ, Hastings A, Edwards HJ (2007) Thresholds and the resilience of Caribbean coral reefs. Nature 450:98-101. https://doi. org/10.1038/nature06252

Mumby PJ, Steneck RS, Adjeroud M et al (2016) High resilience masks underlying sensitivity to algal phase shifts of Pacific coral reefs. Oikos 125:644-655. https://doi.org/10.1111/oik.02673

Munga CN, Mohamed MOS, Amiyo N et al (2012) Status of coral reef fish communities within the Mombasa marine protected area, Kenya, more than a decade after establishment. West Indian Ocean J Mar Sci 10:169-184

Murray G (2007) Constructing paradise: the impacts of big tourism in the Mexican coastal zone. Coast Manag 35:339-355. https://doi. org/10.1080/08920750601169600

Nejati M, Mohamed B, Omar SI (2014) Locals' perceptions towards the impacts of tourism and the importance of local engagement: a comparative study of two islands in Malaysia. Tourism 62:135-146

Olmos-Martínez E, Arizpe-Covarubias OA, Ibañez Perez RM et al (2015) Ecosystem services with tourism potential of the Espíritu Santo Archipelago natural park in Baja California Sur, México. Teoría y Praxis at: www.redalyc.org/html/4561/456144904009/ index.html. Accessed 16 May 2018

Oracion EG, Miller ML, Christie P (2005) Marine protected areas for whom? Fisheries, tourism, and solidarity in a Philippine community. Ocean Coast Manag 48:393-410. https://doi.org/10.1016/j. ocecoaman.2005.04.013

Outra MIH, Sari SK, Sukandar H et al (2016) Engaging dive tourism in sustainable financing and coral reef data collection for better management of Karimunjawa National Park, Indonesia. In: Thirteenth international coral reef symposium. Honolulu, Hawaii, 19-14 June 2016

Pauly D (1995) Anecdotes and the shifting baseline syndrome of fisheries. Trends Ecol Evol 10:430. https://doi.org/10.1016/ S0169-5347(00)89171-5

Perry CT, Morgan KM (2017) Post-bleaching coral community change on southern Maldivian reefs: is there potential for rapid recovery? Coral Reefs 36:1189-1194. https://doi.org/10.1007/ s00338-017-1610-9

Plummer R, Armitage DR, de Loë RC (2013) Adaptive comanagement and its relationship to environmental governance. Ecol Soc 18:21. https://doi.org/10.5751/ES-05383-180121

Polak O, Shasnar N (2012) Can a small artificial reef reduce diving pressure from a natural coral reef? Lessons learned from Eilat, Red Sea. Ocean Coast Manag 55:94-100

Polovina JJ (1990) Assessment of biological impacts of artificial reefs and FADS. In: Symposium on artificial reefs and fish aggregating devices as tools for the management and enhancement of marine fishery resources. Colombo, Sri Lanka, 14-17 May 1990

Polovina JJ, Sakai I (1989) Impacts of artificial reefs on fishery production in Shimamaki, Japan. Bull Mar Sci 44:997-1003

Redding JE, Myers-Miller RL, Baker DM et al (2013) Link between sewage-derived nitrogen pollution and coral disease severity in Guam. Mar Pollut Bull 73:57-63. https://doi.org/10.1016/j. marpolbul.2013.06.002

Renfro B, Chadwick NE (2017) Benthic community structure on coral reefs exposed to intensive recreational snorkeling. PLoS One 12:e0184175. https://doi.org/10.1371/journal.pone.0184175

Roberts CM, Hawkins JP (2000) Fully protected marine reserves: a guide. WWF Endangered Seas Campaign, Washington, DC. Available at: assets.panda.org/downloads/marinereservescolor. pdf. Accessed 24 April 2018

Roberts CM, Mcclea CJ, Veron JEN et al (2002) Marine biodiversity hotspots and conservation priorities for tropical reefs. Science 295:1280-1284. https://doi.org/10.1126/science.1067728

Roche RC, Harvey CV, Harvey JJ et al (2016) Recreational diving impacts on coral reefs and the adoption of environmentally responsible practices within the scuba diving industry. Environ Manag 58:107-116. https://doi.org/10.1007/s00267-016-0696-0

Rogers CS (1990) Responses of coral reefs and reef organisms to sedimentation. Mar Ecol Prog Ser 62:185-202. https://doi.org/10.3354/ meps062185

Sadovy de Mitcheson Y, Cornish A, Domeier M et al (2008) A global baseline for spawning aggregations of reef fishes. Conserv Biol 22:1233-1244. https://doi.org/10.1111/j.1523-1739.2008.01020.x

Samoilys MA, Osuka K, Maina GW et al (2017) Artisanal fisheries on Kenya's coral reefs: decadal trends reveal management needs. Fish Res 186:177-191. https://doi.org/10.1016/j.fishres.2016.07.025

Sandin SA, Smith JE, DeMartini EE et al (2008) Baselines and degradation of coral reefs in the northern Line Islands. PLoS One 3:e1548. https://doi.org/10.1371/journal.pone.0001548

Saragih H (2016) Marketing artificial reef as recreational scuba diving resources: feasibility study for sustainable tourism. In: Proceedings of the 2016 global conference on business, management and Entrepreneurship, Bandung, Indonesia, 08 August 2016

Sary Z, Oxenford HA, Woodley JD (1997) Effects of an increase in trap mesh size on an overexploited coral reef fishery at Discovery Bay, Jamaica. Mar Ecol Prog Ser 154:107-120. https://doi.org/10.3354/ meps 154107

Satria A, Matsuda Y, Sano M (2004) Multilevel conflicts in community based coral reef management systems: case study in West-Lombok, Indonesia. In: IIFET 2004 Japan proceedings, Tokyo, Japan, 20-30 July 2004

Schultz L, Duit A, Folke C (2011) Participation, adaptive comanagement, and management performance in the World Network 
of Biosphere Reserves. World Dev 39:662-671. https://doi. org/10.1016/j.worlddev.2010.09.014

Scott ME, Smith JA, Lowry MB et al (2015) The influence of an offshore artificial reef on the abundance of fish in the surrounding pelagic environment. Mar Freshw Res 66:429-437. https://doi. org/10.1071/MF14064

Seaman W, Jensen AC (2000) Purposes and practices of artificial reef evaluation. In: Seaman W (ed) Artificial reef evaluation with application to natural marine habitats. CRC Press, Boca Raton, pp 1-20

Sloan K (1987) Valuing Heron Island: preliminary results. In: 16th conference of economists. Surfers Paradise, Queensland, Australia, 23-27 August 1987

Smith SV, Kimmerer WJ, Laws EA et al (1981) Kaneohe Bay sewage diversion experiment: perspectives on ecosystem responses to nutritional perturbation. Pac Sci 35:279-395. https://hdl.handle. net/10125/616

Smith JA, Lowry MB, Champion C et al (2016) A designed artificial reef is among the most productive marine fish habitats: new metrics to address 'production versus attraction'. Mar Biol 163:188. https:// doi.org/10.1007/s00227-016-2967-y

Spalding M, Burke L, Wood SA et al (2017) Mapping the global value and distribution of coral reef tourism. Mar Policy 82:104-113. https://doi.org/10.1016/j.marpol.2017.05.014

Stolk P, Markwell K, Jenkins JM (2007) Artificial reefs as recreational scuba diving resources: a critical review of research. J Sustain Tour 15:331-350. https://doi.org/10.2167/jost651.0

Tabata RS (1992) Scuba-diving holidays. In: Weiler B, Hall CM (eds) Special interest tourism. Belhaven Press, New York, pp 171-184

Techera E (2007) Customary law and community based conservation of marine areas in Fiji. In: 6th Global conference in environmental justice and global citizenship. Oxford, UK, 2-5 July 2007

Teh LCL, Sumaila UR (2013) Contribution of marine fisheries to worldwide employment. Fish Fish 14:77-88. https://doi. org/10.1111/j.1467-2979.2011.00450.x

Thur SM (2010) User fees as sustainable financing mechanisms for marine protected areas: an application to the Bonaire National Marine Park. Mar Policy 34:63-69. https://doi.org/10.1016/j. marpol.2009.04.008

Tupper M, Asif F, Garces LR et al (2015) Evaluating management effectiveness of marine protected areas at seven selected sites in the Philippines. Mar Policy 56:33-42

United Nations (2018) Country classifications. In: World economic situation and prospects, New York. Available at: https://www.un.org/ development/desa/dpad/wp-content/uploads/sites/45/publication/ WESP2018_Full_Web-1.pdf. Accessed 7 May 2018

Van Beukering PJH, Cesar HSJ (2004) Ecological economic modelling of coral reefs: evaluating tourist overuse at Hanauma Bay and algae blooms at the Kihei Coast. Pac Sci 58:243-260. https://doi. org/10.1353/psc.2004.0012

Van Beukering PJH, Haider W, Wolfs E et al (2006) The economic value of the coral reefs of Saipan, Commonwealth of the Northern Mariana Islands. CEEC Report, p 153

Van Beukering PJH, Sarkis S, van der Putten L et al (2015) Bermuda's balancing act: the economic dependence of cruise and air tourism on healthy coral reef. Ecosyst Serv 11:76-86. https://doi.org/10.1016/j. ecoser.2014.06.009

Vianna GMS, Meekan MG, Pannell DJ et al (2012) Socio-economic value and community benefits from shark-diving tourism in Palau: a sustainable use of reef shark populations. Biol Conserv 145:267277. https://doi.org/10.1016/j.biocon.2011.11.022

Walmsley S, Purvis J, Ninnes C (2006) The role of small-scale fisheries management in the poverty reduction strategies in the Western Indian Ocean region. Ocean Coast Manag 49:812-833. https://doi. org/10.1016/j.ocecoaman.2006.08.006

Webler T, Jakubowsky K (2016) Mitigating damaging behaviors of snorkelers to coral reefs in Puerto Rico through a pre-trip media-based intervention. Biol Conserv 197:223-228. https://doi.org/10.1016/j. biocon.2016.03.012

Weeks R, Jupiter SD (2013) Adaptive Comanagement of a marine protected area network in Fiji. Conserv Biol 27:1234-1244. https://doi. org/10.1111/cobi.12153

Weijerman M, Williams I, Gutierrez J et al (2016) Trends in biomass of coral reef fishes, derived from shore-based creel surveys in Guam. Fish Bull 114:237-257. https://doi.org/10.7755/FB.114.2.9

Wells S, Ravilious C, Corcoran E (2006) In the front line: shoreline protection and other ecosystem services from mangroves and coral reefs. In: UNEP-WCMC, Cambridge, UK. Available at: https:// www.icriforum.org/sites/default/files/in_front_line.pdf. Accessed 12 May 2018

Yacob MR, Shuib A, Mamat MF et al (2007) Local economic benefits of ecotourism development in Malaysia: the case of Redang Island Marine Park. Int J Econ Manage 1:365-386

Yacob MR, Radam A, Shuib A (2009) A contingent valuation study of marine parks ecotourism: the case of Pulau Payar and Pulau Redang in Malaysia. J Sustain Dev 2:95-105. https://doi.org/10.5539/jsd. v2n2p95

Yeo BH (2004) The recreational benefits of coral reefs: a case study of Pulau Payar Marine Park, Kedah, Malaysia. In: Economic valuation and policy priorities for sustainable management of coral reefs. WorldFish Center. Available at: http://www.worldfishcenter.org/ Pubs/coral_reef/pdf/section2-7.pdf. Accessed 25 April 2018

Young MAL, Foale S, Bellwood DR (2015) Dynamic catch trends in the history of recreational spearfishing in Australia. Conserv Biol 29:784-794. https://doi.org/10.1111/cobi.12456

Zeller D, Harper S, Zylich K et al (2015) Synthesis of underreported small-scale fisheries catch in Pacific island waters. Coral Reefs 34:25-39. https://doi.org/10.1007/s00338-014-1219-1

Zhang LY, Chung S, Qiu J (2016) Ecological carrying capacity assessment of diving site: a case study of Mabul Island, Malaysia. J Environ Manag 183:253-259. https://doi.org/10.1016/j. jenvman.2016.08.075

Zimmerhackel JS, Pannell DJ, Meekan M (2016) Diving tourism and fisheries in marine protected areas: market values and new approaches to improve compliance in the Maldives Shark Sanctuary. Working paper 1610. School of Agricultural and Resource Economics, University of Western Australia, Crawley, Australia

Open Access This chapter is licensed under the terms of the Creative Commons Attribution 4.0 International License (http://creativecommons. org/licenses/by/4.0/), which permits use, sharing, adaptation, distribution and reproduction in any medium or format, as long as you give appropriate credit to the original author(s) and the source, provide a link to the Creative Commons license and indicate if changes were made.

The images or other third party material in this chapter are included in the chapter's Creative Commons license, unless indicated otherwise in a credit line to the material. If material is not included in the chapter's Creative Commons license and your intended use is not permitted by statutory regulation or exceeds the permitted use, you will need to obtain permission directly from the copyright holder.

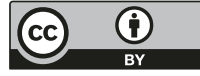

